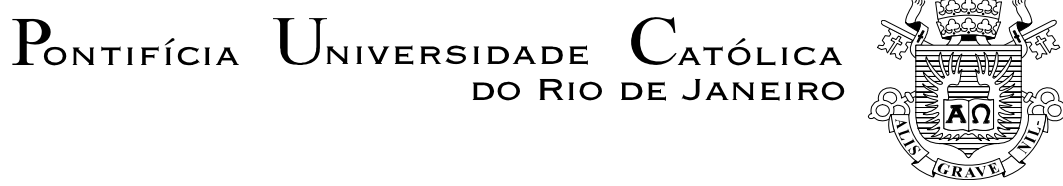

Almir Fraga Lugon

Princípio da insignificância sob uma perspectiva constitucional

Dissertação de Mestrado

Dissertação apresentada ao Programa de PósGraduação em Direito da PUC-Rio como requisito parcial para obtenção de título em Mestre em Direito.

Orientador: Prof. Noel Struchiner 


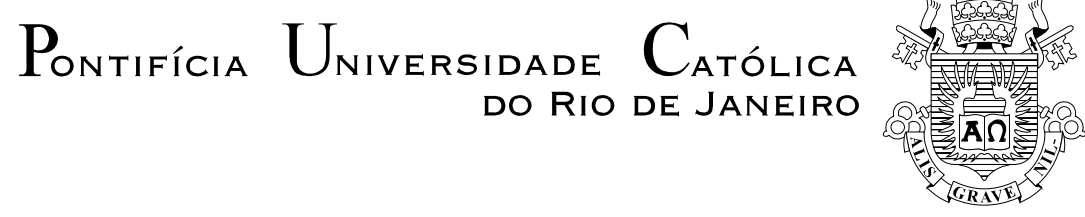

Almir Fraga Lugon

\title{
Princípio da insignificância sob uma perspectiva constitucional
}

\begin{abstract}
Dissertação apresentada como requisito parcial para a obtenção do grau de Mestre pelo Programa de Pós-Graduação em Direito do Departamento de Direito da PUC-Rio. Aprovada pela Comissão Examinadora abaixo assinada.
\end{abstract}

Prof. Noel Struchiner

Orientador

Departamento de Direito - PUC-Rio

Prof. Rachel Barros Nigro

Departamento de Direito - PUC-Rio

Prof. Fábio Carvalho Leite

Departamento de Direito - PUC-Rio

Profa. Monica Herz

Vice-Decana de Pós-Graduação do Centro de

Ciências Sociais - PUC-Rio

Rio de Janeiro, 11 de junho de 2014. 
Todos os direitos reservados. É proibida a reprodução total ou parcial do trabalho sem autorização da universidade, do autor e do orientador.

\section{Almir Fraga Lugon}

Graduou-se em direito no ano de 2007 na Faculdades Integradas de Vitória (FDV). Pós graduou-se em Ciências Penais em 2009. É professor de Direito Penal e Direito Processual Penal da Rede de Ensino DOCTUM, unidades de Caratinga/MG e Manhuaçu/MG.

Ficha Catalográfica

Lugon, Almir Fraga.

Princípio da insignificância sob uma perspectiva constitucional / Almir Fraga Lugon; orientador: Noel Struchiner. - Rio de Janeiro: PUC, Departamento de Direito, 2014.

v. 72 f.: il. ; $29,7 \mathrm{~cm}$

1. Dissertação (mestrado) - Pontifícia Universidade Católica do Rio de Janeiro, Departamento de Direito.

Inclui referências bibliográficas.

1. Direito - Dissertações. 2. Princípio da insignificância. 3. Teoria do delito. 4. Critérios de aplicação. 5. Princípios constitucionais penais. I. Struchiner, Noel. II Pontifícia Universidade Católica do Rio de Janeiro. Departamento de Direito. III. Título. 
Para minha família e Mariane, pelo apoio, carinho e amor. 


\section{Agradecimentos}

A Deus, por sempre me guiar e me dar força nos momentos difíceis, como terminar o presente trabalho, mesmo diante de todas as dificuldades no curso do mestrado.

Ao meu orientador, Professor Noel Struchiner, pelas orientações e também por seu admirável nível de conhecimento.

A todos os professores do Curso de Mestrado.

Aos meus pais, pelo amor e apoio a todo instante e por sempre investirem na minha educação, mesmo em períodos de dificuldades.

Aos meus alunos, pelas diversas homenagens recebidas que me motivam a buscar uma qualificação melhor e ao estudo constante para retribuir o reconhecimento.

Aos amigos da Polícia Civil de Minas Gerais, pela luta constante no árduo trabalho de combate à criminalidade.

A minha irmã Anita e meu cunhado/irmão Marcus, pelo apoio incondicional.

Ao Guilherme e Luiz Henrique pelos momentos de alegria que me proporcionam.

A toda família da Mariane por me acolherem e amenizarem a distância da minha família.

A Mariane, meu amor. 


\section{Resumo}

Lugon, Almir Fraga; Struchiner, Noel. Princípio da insignificância sob uma perspectiva constitucional. Rio de Janeiro, 2014, 72 p. Dissertação de Mestrado - Departamento de Direito, Pontifícia Universidade Católica do Rio de Janeiro.

Esta dissertação analisa o princípio da insignificância sob uma perspectiva constitucional e analisa as consequências de sua aplicação no cenário atual brasileiro. Há uma discussão sobre a evolução nos estudos da teoria do crime, para uma localização do princípio dentro do conceito analítico do crime, de forma que demonstramos ter a natureza jurídica de excludente de tipicidade em sua dimensão material. Trata-se de princípio decorrente lógico do princípio da intervenção mínima em sua característica da fragmentariedade. O princípio em tela possui uma importante função interpretativa ao servir de filtro valorativo da tipicidade, excluindo do direito penal conduta e/ou resultados irrelevantes. Os critérios definidos pela jurisprudência auxiliam o intérprete na aplicação do princípio de forma justa e atendendo às finalidades do Direito Penal.

\section{Palavras-chave}

Princípio da insignificância; Teoria do delito; Critérios de aplicação; Princípios constitucionais penais. 


\section{Abstract}

Lugon, Almir Fraga; Struchiner, Noel (Advisor). Principle of insignificance under a constitutional perspective. Rio de Janeiro , 2014, 72 p . MSc. Dissertation - Departamento de Direito, Pontifícia Universidade Católica do Rio de Janeiro.

This dissertation analyzes the principle of insignificance under a constitutional perspective and examines the consequences of its application in the current Brazilian scenario. There is a discussion on developments of the theory of the crime, in order to locate the principle in the analytical concept of the crime, so we demonstrate it as a exclusion of typicality in its material dimension. It is a logical principle derived from the principle of minimum intervention in their feature fragmentariedade. The principle on focus has an important interpretative function to serve as an evaluative filter, excluding of criminal law either irrelevant behaviour and or irrelevant results. The criteria established by case law assists the interpreter in fair the application of the principle and meeting the purposes of criminal law .

\section{Keywords}

Principle of insignificance; Theory of crime; Application criteria; Criminal constitutional principles 


\section{Sumário}

Introdução

1. Direito Penal e Política criminal: os avanços da teoria do crime para uma adequada compreensão e localização do princípio da insignificância 15

1.1. Missão do Direito Penal e a Constituição

1.2. Princípios constitucionais basilares para a compreensão do princípio da insignificância $\quad 21$

1.2.1. Princípio da dignidade da pessoa humana 23

1.2.2. Princípio da intervenção mínima 25

1.2.3. Princípio da materialização do fato 27

1.2.4. Princípio da legalidade 28

1.2.5. Princípio da proporcionalidade 29

1.2.6. Princípio da lesividade ou ofensividade 30

1.3. A evolução do conceito analítico de crime: alocação da análise da insignificância na teoria no crime

2. O princípio da insignificância sob uma perspectiva constitucional 35

2.1. Conceito, origem, previsão legal e natureza jurídica 35

2.1.1. Conceito 35

2.1.2. Origem 38

2.1.3. Previsão legal 39

2.1.4. Natureza jurídica 40

2.1.4.1. Excludente de antijuridicidade $\quad 40$

2.1.4.2. Excludente de culpabilidade 41

2.1.4.3. Excludente de tipicidade 42

2.1.4.4. Natureza ubíqua (tipicidade/antijuridicidade) 43

2.1.5. A quem incumbe a aplicação do princípio da insignificância? 43

2.1.6. Utilitarismo como justificativa para o princípio da insignificância 45

2.2. Princípio da insignificância $X$ princípio da irrelevância penal do fato 
3. Critérios de aplicação do princípio da insignificância 48

3.1. Critérios de aplicação segundo a doutrina 48

3.2. Critérios de aplicação segundo a jurisprudência 49

3.2.1. Ausência de periculosidade social da ação 50

3.2.2. Reduzido grau de reprovabilidade do comportamento 51

3.2.3. A mínima ofensividade da conduta 52

3.2.4. A inexpressividade da lesão jurídica provocada 53

3.3. Consequencia da aplicação dos princípios da insignificância e da irrelevância penal do fato nas diversas modalidades de crimes 58

3.3.1 Insignificância e crimes contra o patrimônio sem violência e $\begin{array}{ll}\text { grave ameaça } & 58\end{array}$

3.3.2. Insignificância e crimes contra o patrimônio com violência ou grave ameaça $\quad 59$

3.3.3. Insignificância e crimes contra a Administração pública 59

3.3.4. Insignificância e porte de droga para uso pessoal 60

3.3.5. Insignificância no descaminho e crimes contra a ordem tributária

61

3.3.6. Insignificância e ato infracional 62

3.3.7. Insignificância e crimes ambientais 63

3.3.8. Insignificância e posse ilegal de arma de fogo 63

3.3.9. Insignificância, réu reincidente e reiteração de conduta 65

3.3.9.1. Multirreincidência ou reiteração cumulativa: 65

3.3.9.2. Multirreincidência ou reiteração não cumulativa: 65

3.3.9.3. Fato único insignificante cometido por réu reincidente: 67

$\begin{array}{ll}\text { 4. Conclusão } & 68\end{array}$

$\begin{array}{ll}\text { 5. Referências bibliográficas } & 70\end{array}$ 


\section{Introdução}

Este trabalho visa analisar a aplicação do princípio da insignificância no direito penal sob uma perspectiva constitucional, construindo um embasamento teórico para o estudo do princípio em tela, bem como tentando criar critérios ou vetores para uma correta aplicação do princípio atrelada às finalidades do direito penal.

Para tanto, faremos uma análise prévia de alguns pontos importantes para a adequada compreensão do tema, entre os quais: a missão do direito penal e o papel da Constituição na seleção dos bens jurídicos tutelados pelo direito penal, os avanços na teoria do crime, bem como a análise dos critérios estabelecidos para a aplicação do princípio em estudo, tanto na doutrina, quanto na jurisprudência.

Neste contexto, após uma explanação sobre os pontos supracitados, analisaremos que o princípio da insignificância deriva do princípio da intervenção mínima, o qual, por sua vez, decorre da adoção de um modelo de Estado liberal social e democrático de direto, preocupado com a autonomia dos indivíduos, utilizando a maléfica intervenção do direito penal apenas para as lesões ou perigo de lesões aos bens jurídicos de maior relevância. Desta forma, visualizamos o princípio da insignificância como um princípio com importante função interpretativa, desempenhando um papel de filtro valorativo da tipicidade penal, excluindo da incidência penal condutas e/ou resultados insignificantes em relação aos bens jurídicos tutelados.

A temática aqui tratada irá demonstrar que a filosofia utilitarista do cálculo do custo/benefício pode nos ajudar na justificação da aplicação do princípio da insignificância, de forma que a internalização desta norma, é mais útil para as finalidades do direito penal de proteção dos bens jurídicos e de restrição da intervenção estatal, de forma que a não aplicação do princípio geraria uma imensa quantidade de ações sobre fatos ínfimos, o que, por sua vez, acarretaria uma ineficácia estatal em relação aos fatos efetivamente relevantes, além das 
consequências drásticas da intervenção penal serem totalmente desproporcionais em relação às condutas e/ou resultados jurídicos irrelevantes.

A discussão em tela passa pelos estudos dos métodos e objetivos do direito penal, levando uma minuciosa e esclarecida análise sobre a evolução do estudo do direito penal pelas escolas teóricas até chegarmos ao atual momento da visão doutrinária sobre o delito.

O presente trabalho analisa o princípio da insignificância e explana sobre temas que ao nosso modo contribuem para a correta aplicação e entendimento do princípio em tela.

O primeiro capítulo analisa os atuais movimentos de estudo do direito penal como o funcionalismo racional o qual propõe um estudo das categorias do delito sob a perspectiva das finalidades político-criminais, pois isto é imprescindível para a compreensão de onde encontra-se a discussão sobre o princípio da insignificância no Direito Penal.

O fato é que não há como o legislador, ao selecionar todos os fatos humanos indesejados que mereceram a intervenção do direito penal, prever e inserir na norma todas as circunstâncias ou graus de lesão para a incidência do tipo penal. Desta forma, esta tarefa valorativa da incidência do tipo penal, ficou a cargo do aplicador da lei.

Neste contexto, surge o princípio da insignificância com sua importante função interpretativa, funcionando como um filtro valorativo do âmbito de incidência do direito penal, excluindo as condutas e/ou resultados incapazes de gerar relevantes lesões ou perigo de lesões aos bens jurídicos tutelados, evitando uma desproporção causada pela intervenção penal a uma conduta ínfima apenas por ser formalmente típica ${ }^{1}$.

${ }^{1}$ TOLEDO, Francisco de Assis. Princípios básicos de direito penal. $5^{a}$ ed. São Paulo: Saraiva, 2000. P. 129. 
Em relação à localização do estudo do princípio da insignificância dentro do estudo da teoria do crime é importante observar que a doutrina penal há algum tempo analisa o crime sob uma ótica analítica, separando cada substrato do crime e seus respectivos elementos. Desta forma, de acordo com a doutrina majoritária, crime é constituído dos substratos chamados de: fato típico, ilicitude ou antijuridicidade e culpabilidade e, possui como consequência, a punibilidade ${ }^{2}$.

No presente trabalho o foco será sobre o fato típico, mais precisamente sob a tipicidade, uma vez que aqui é que terá incidência o princípio da insignificância. Neste ponto, cabe salientar que o fato típico, mais precisamente na tipicidade que, antigamente, se restringia à mera subsunção do fato ao tipo penal incriminador. No entanto, Claus Roxin, buscando evitar a expansão das condutas incriminadoras e adequar o direito penal aos princípios de política criminal, passou a defender que cada uma das categorias do delito devem ser estudadas sob esta ótica, ou seja, com base em tais princípios ${ }^{3}$. Assim, no âmbito da tipicidade, por exemplo, defende que ela possui uma dimensão formal, em que se analisa apenas à subsunção do fato à norma e uma dimensão material, em que será valorado se a conduta e/ou resultado causou relevante e intolerável lesão ou perigo de lesão ao bem jurídico tutelado e é neste ponto em que se encontra inserido a atuação do princípio da insignificância, o qual excluirá a tipicidade na sua dimensão material.

Já o segundo capítulo analisa detidamente o princípio em tela, conceituando-o e analisando pontos importantes, como os agentes responsáveis pela a aplicação, bem como a sua diferenciação com o princípio da irrelevância penal do fato.

O chamado crime insignificante ou infração bagatelar não possui relevância penal ou por ausência de periculosidade da conduta perpetrada ou por irrelevância do resultado jurídico ou ambos. Luiz Flávio Gomes observa que as

\footnotetext{
2 CIRINO DOS SANTOS, Juarez. A moderna teoria do fato punível. Rio de Janeiro: Freitas Bastos, 2001, p. 5.

3 GOMES, Luiz Flávio. Direito Penal: Fundamentos e limites do Direito Penal/ Luiz Flávio Gomes, Antonio García-Pablos de Molina. - São Paulo: Editora Revista dos Tribunais, 2012. (Coleção ciências criminais; v.1). P. 619. A partir de agora citado apenas como GOMES, Luiz Flávio. Direito Penal: Fundamentos e limites do Direito Penal.
} 
três situações podem ocorrer e gerar a ausência da incidência penal, por exemplo, aquele que auxilia uma inundação dolosa com um copo d’água não pode ser criminalizado, pois sua ação foi irrelevante, ainda que o resultado tenha sido devastador. Por outro lado, quem subtrai uma caixa de fósforo de um supermercado não deve ser criminalizado, pelo fato do resultado jurídico ter sido irrelevante. E, por fim, exemplifica o caso de um acidente de trânsito por culpa levíssima do condutor e que gera apenas um arranhão em uma vítima, onde teríamos tanto uma conduta irrelevante, quanto o resultado jurídico gerado, o que também não receberia a incidência do direito penal ${ }^{4}$. Desta forma, concluímos que na tipicidade material deverá ocorrer um juízo valorativo sobre a conduta e sobre o resultado jurídico gerado.

No presente estudo será observado que embora alguns critiquem a aplicação do princípio em tela por ausência de norma expressa, é possível verificar expressamente o princípio em tela num dos códigos mais repressivos do nosso ordenamento jurídico. O Código penal militar em seu artigo 209, §6 prescreve que "no caso de lesões levíssimas o juiz pode considerar a infração como disciplinar”, da mesma forma determina o art. $240, \S 1^{\circ}$ para o furto insignificante ${ }^{5}$.

O terceiro capítulo trata dos polêmicos critérios para a aplicação do princípio da insignificância, sendo fato tormentoso sobre o tema, a falta de critérios e a subjetividade na aplicação do princípio em tela.Desta forma, analisaremos tanto os critérios definidos pela doutrina (valoração da ação e resultado e danosidade social), quanto os vetores definidos pelo Supremo Tribunal Federal(a) a mínima ofensividade da conduta do agente, (b) a nenhuma periculosidade social da ação, (c) o reduzidíssimo grau de reprovabilidade do comportamento e (d) a inexpressividade da lesão jurídica provocada).

\footnotetext{
${ }^{4}$ GOMES, Luiz Flávio. Princípio da insignificância e outras excludentes de tipicidade. $3^{\mathrm{a}} \mathrm{ed}$. rev. atual. eampl.- São Paulo: Editora Revista dos Tribunais, 2013. p. 19.

${ }^{5}$ Decreto lei 1001/69.
} 
Ao final será abordada uma importante discussão se o princípio da insignificância pode definir apenas critérios objetivos (analisar somente o fato criminoso) ou se pode analisar critérios subjetivos (o autor do delito). 


\section{1 \\ Direito Penal e Política criminal: os avanços da teoria do crime para uma adequada compreensão e localização do princípio da insignificância}

Neste capítulo, iremos, prima facie, fixar a missão precípua do direito penal como de proteção de bens jurídicos, pois, como veremos, isto será importante para fundamentar a aplicação do princípio da insignificância. Posteriormente, faremos uma explanação sobre os princípios que fundamentam a aplicação do princípio da insignificância, sem os quais não é possível uma correta compreensão da infração bagatelar.

Por fim, iremos realizar um breve estudo sobre a evolução da teoria do crime, visando situar onde se encontra, dentro da teoria do crime, o estudo sobre o princípio em tela, o que será imprescindível para avançarmos o debate sobre o tema.

\section{1}

\section{Missão do Direito Penal e a Constituição}

Num enfoque sociológico, o Direito Penal é a área do ordenamento jurídico que limita o direito de punir do estado, selecionando comportamentos humanos antissociais, determinando sanções para assegurar uma boa convivência entre os membros deuma sociedade ${ }^{6}$.

Trata-se de um sistema social dinâmico, pois acompanha a evolução cultural da sociedade, uma vez que determinados comportamentos com o passar do tempo, deixam de merecer a intervenção drástica do direito penal, tendo em vista que a sociedade passar a encarar tais condutas como socialmente aceitáveis.

\footnotetext{
${ }^{6}$ MIR PUIG, Santiago. Derecho Penal: parte geral. 3. Ed. Barcelona: P.P.U, 1990, p. 4-5. A partir de agora citado apenas como MIR PUIG, Santiago: Derecho penal: parte geral.
} 
O Direito penal se mostra como parte de um sistema de controle social e fazem parte deste sistema, tanto os mecanismos de controle informal (família, igreja, escola, etc.), quanto os demais ramos do direito (mecanismos de controle formal) ${ }^{7}$. Mas qual é a peculiaridade do direito penal em relação aos demais mecanismos de controle social? O direito penal se mostra como a forma mais drástica de intervenção estatal em face das sanções previstas para violação das condutas selecionadas (penas ou medidas de segurança) ${ }^{8}$.

Em face da drástica forma de intervenção do direito penal, este deverá ser acionado apenas quando os instrumentos de controle social informal e os demais meios formais fracassem, de forma que a intervenção penal deve estar reservada apenas quando a conduta antissocial "releve uma especial relevância, ou seja, uma concreta, transcendental, grave e intolerável forma de ofensa a um bem jurídico relevante"(ultima ratio) ${ }^{9}$.

Mas o direito penal não se reserva apenas para assegurar a observância da norma, mas sim para proteção de valores importantes para manutenção da paz social. Desta forma, a doutrina vem salientando que a missão primordial do direito penal é a tutela de bens jurídicos fundamentais para o indivíduo e para a comunidade $^{10}$.

Tendo em vista a gravidade da forma de intervenção, o direito penal se reserva a tutelar apenas as lesões graves e intoleráveis aos bens jurídicos mais valiosos, de modo que sua função é essencial para a manutenção da paz social, tendo em vista que esta só será obtida com a garantia de preservação dos referidos bens, essenciais para a vida em sociedade.

\footnotetext{
${ }^{7}$ ZUGALDIA ESPINAR, J.M. Fundamentos de derecho penal. 3. Ed. Valencia: TirantloBlanch, 1993. P. 28 e ss.

${ }^{8}$ MIR PUIG, Santiago: Derecho penal: parte geral. P. 5.

${ }^{9}$ Idem ibidem.

${ }^{10}$ Neste sentido: PRADO, Luiz Regis. Bem jurídico penal e Constituição. P. 47; BATISTA, Nilo. Introdução crítica ao direito penal brasileiro. p. 48; GRECO, Rogério. Curso de Direito Penal parte geral.9 ed. Rio de Janeiro: Impetus, 2007. p. 4; GOMES, Luiz Flávio. Direito Penal: Fundamentos e limites do Direito Penal.p. 198-199; GUSTAVO, Junqueira/VANZOLINI, Patrícia. Manual de direito penal. São Paula: Saraiva, 2013, p. 38; ESTEFAM, André/GONÇALVES, Victor Eduardo Rios. Direito penal esquematizado: parte geral. 2 ed. rev. e atual. São Paulo: Saraiva, 2013, p. 133. MASSON, Cleber Rogério. Direito penal esquematizado: parte geral - vol. 1. $5^{\text {a }}$ ed. São Paulo: Método, 2011, p. 45.
} 
A finalidade do direito penal é matéria altamente controvertida, mas a doutrina vem majoritariamente apontando de que o objetivo precípuo é a proteção dos bens jurídicos mais valiosos, uma vez que tal fim se ajusta a uma finalidade político criminal de um Estado constitucional e humanista de direito, estando em função da pessoa humana, assegurando condições para a vida em sociedade, evitando uma utilização ideológica deste instrumento de controle e intervindo o mínimo possível na liberdade das pessoas ${ }^{11}$.

Sobre a missão do Direito penal, cabe ressaltar os ensinamentos de Luiz Flávio Gomes ${ }^{12}$, senão vejamos:

A missão de tutela de bens jurídicos, para além de constituir uma garantia essencial do Direito penal, surge como uma das importantes proposições de um programa político-criminal típico de um Estado constitucional e humanista de Direito, de cariz social e participativo, fundado tanto em valores essenciais (assim, por exemplo, a dignidade humana, liberdade e justiça) como na concepção de que o Estado não deve estar a serviço dos que governam ou detêm o poder, senão em função da pessoa humana (omne jus hominum causa introductum est), em várias dimensões: a) que está obrigado a assegurar as condições essenciais, seja para o desenvolvimento de sua personalidade, seja para a vida em sociedade; b) que não pode promover, defender ou impor qualquer ideologia ou qualquer ordem moral ou religiosa (secularização do Direito penal); c) que deve tolerar e incentivar o modelo pluralista e democrático de convivência, o que significa que deve intervir o menos possível na liberdade humana (intervenção mínima) e jamais castigar 'meras imoralidades'.

Assim, como o direito penal tem como principal objetivo a tutela dos bens jurídicos mais importantes e contra relevantes lesões ou perigo de lesões, deve ter como base o texto constitucional para cumprir fielmente sua missão ${ }^{13}$. Desta forma, como observa Márcia Dometila Lima de Carvalho, “a sanção penal será precedente e legítima, quando absolutamente necessária para a salvação das bases fundamentais em que se assenta a sociedade justa e livre que a Constituição visa construir ${ }^{14,}$.

\footnotetext{
${ }^{11}$ MIR PUIG, Santiago. Derecho penal: parte geral. p. 136-137.

${ }^{12}$ GOMES, Luiz Flávio. Direito Penal: Fundamentos e limites do Direito Penal. p. 250-251.

${ }^{13}$ SILVA, Ivan Luiz da. Princípio da insignificância no direito penal. $2^{\mathrm{a}}$ Edição. Curitiba: Juruá, 2011, p. 68. A partir de agora citado apenas como SILVA, Ivan. Princípio da insignificância.

${ }^{14}$ CARVALHO, Márcia Dometila Lima de. Fundamentação constitucional do direito penal. Porto Alegre: Sérgio Antonio Fabris Editor, 1992. P. 23-24.
} 
Ocorre que, falar que ao Direito Penal incumbe precipuamente a tarefa de tutela de bens jurídicos, pode não significar muita coisa se não delinearmos o que seria bem jurídico, sendo que trata-se de outro fator nada pacífico na doutrina. A escola penal conhecida como "positivistas” identificaram de forma altamente imprecisa como "interesses do homem”, os neokantianos, classificaram como valores consagrados na Constituição, sendo que muitas vezes existe uma confusão entre bens jurídicos penalmente tutelados e a própria Ética social ${ }^{15}$.

A visão ético-social alerta que a principal finalidade do direito penal não seria a proteção dos bens jurídicos, porque senão a intervenção penal seria sempre tardia, mas sim incutir na sociedade a observância de não se realizar o comportamento definido na norma. Ocorre que, Luiz Flávio Gomes ${ }^{16}$, bem adverte sobre os perigos de uma vinculação entre direito e moral, a saber:

Em uma sociedade pluralista e democrática não pode ser incumbência do Direito penal incidir na esfera interna do indivíduo, modificando seus padrões de valores (aliás, é bem provável que o Estado, mesmo que quisesse, jamais conseguiria esse desideratum). Tal ingerência é abusiva e imprópria, quando concretizada pelo Direito. Nada mais perigoso, por outro lado, que confundir as fronteiras do Direito com a Moral, pretendendo que o primeiro se transforme em instrumento de atitudes de adesão e fidelidade.

Esta finalidade de exclusiva proteção a bens jurídicos essenciais constitui uma barreira ao Direito punitivo estatal, que já não está autorizado a criminalizar condutas morais ou éticas das pessoas. De forma que as pessoas não podem ser punidas pelo que são ou o que pensa, mas somente pelo que fazem (direito penal do fato $)^{17}$.

O fato é que a doutrina vem apontado a Constituição como ponto de partida para esta teoria do bem jurídico ${ }^{18}$, uma vez que ela trás as bases jurídicas do Estado que pretende consolidar, influenciando na interpretação de todo ordenamento jurídico. A ligação entra os valores constitucionais (e internacionais) e a política criminal é imprescindível para a criação de um modelo capaz de

\footnotetext{
${ }^{15}$ GOMES, Luiz Flávio. Direito Penal: Fundamentos e limites do Direito Penal.p. 199-200.

${ }^{16}$ Idem ibidem.p. 204-205.

${ }^{17}$ GOMES, Luiz Flávio. Direito Penal: Fundamentos e limites do Direito Penal.p. 252-253.

18 PRADO, Luiz Regis. Bem jurídico-penal e Constituição. São Paulo: Revista dos Tribunais, 1999. P. 50 e ss.
} 
intervir minimamente na sociedade e ao mesmo tempo, possibilite uma solução adequada e justa para os problemas advindos do convívio social ${ }^{19}$.

Acerca do papel da Constituição na seleção dos bens jurídicos, Luiz Flávio Gomes $^{20}$ observa que

O legislador é o titular (exclusivo) do desenho da política criminal, assim como da seleção dos bens jurídicos, mas, de qualquer maneira, deve agir dentro dos limites da Constituição. Está justificado o recurso à ameaça penal somente quando o bem jurídico é constitucionalmente legítimo e conta com elevada importância social (...) a Constituição não proporciona critérios de orientação positiva que marquem o que deve ser bem jurídico com caráter prévio à sua consagração normativa, mas sim proporciona critérios interpretativos com relação ao alcance do bem jurídico uma vez que este foi elevado à regulação positiva.

E Paulo de Souza Queiroz ${ }^{21}$, complementa:

É a Constituição que delineia o perfil do Estado, assinalando os fundamentos, objetivos e princípios basilares (particularmente, arts. $1^{\circ}$ ao $5^{\circ}$ da $\mathrm{CF}$ ) que vão governar a sua atuação. Logo, como manifestação da soberania do Estado, o Direito e, em especial, o Direito Penal partem da anatomia política (Focault), devem expressar essa conformação político-jurídica (estatal) ditada pela Constituição, mas, mais do que isso, devem traduzir os valores superiores da dignidade da pessoa humana, da liberdade, da justiça e da igualdade, uma vez que o catálogo de direitos fundamentais constitui, como ressalta Gómez de la Torre, o núcleo específico de legitimação e limite da intervenção penal e que, por sua vez, delimita o âmbito do punível nas condutas delitivas.

Neste contexto, a Constituição exerce uma dupla tarefa, firmando bases para auxiliar o legislador na seleção dos bens imprescindíveis para a vida em sociedade, bem como impedindo que este criminalize comportamentos que importem em violação à direitos constitucionalmente protegidos ${ }^{22}$.

Sobre a teoria do bem jurídico penal Luiz Flávio Gomes observa que

Não há como deixar de reconhecer que, apesar de todos os problemas que apresenta, inclusive de realização prática, é a única que permite difundir uma

\footnotetext{
${ }^{19}$ GOMES, Luiz Flávio. Direito Penal: Fundamentos e limites do Direito Penal.p. 52-53.

${ }^{20}$ Idem ibidem. P. 294.

${ }^{21}$ QUEIROZ, Paulo de Souza. Direito penal - Introdução crítica. São Paulo: Saraiva, 2001. p. 1718.

${ }^{22}$ GRECO, Rogério. Curso de Direito Penal parte geral.9 ed. Rio de Janeiro: Impetus, 2007. p. 6. Importante observação a ser feita é que os doutrinadores penalistas não fazem uma reflexão se os bens jurídicos tutelados pelo Código Penal, estão compatíveis com a Constituição Federal.
} 
pluralidade de exigências essenciais para a configuração de um Direito penal típico de Estado constitucional e humanista de Direito, tais como: de orientar o juiz na determinação do verdadeiro conteúdo do fato típico; de permitir assim uma interpretação não afastada da realidade social da qual a norma é consequência e à qual se aplica; de possibilitar uma contínua adequação do conteúdo prescritivo das leis penais, em consonância com os objetivos da sociedade; de assegurar que o acusado seja chamado a responder não por qualquer violação de deveres de fidelidade ou pela Gesinnung, senão pela realização de um fato objetivo antijurídico; de oferecer as bases para uma construção racional do Código Penal fundada em ofensas objetivamente individualizáveis e para graduar a entidade das relativas sanções de modo proporcional à distinta gravidade da ofensa; de permitir um controle em termos substanciais das razões pelas quais o legislador instituiu uma certa disposição, como o propósito de valorar a correção da técnica legislativa empregada; de constituir o ponto de referência para o juízo de legitimidade constitucional das normas penais, com base na relação que se estabelece entre o valor tutelado, moda da tutela e diretrizes contidas na Constituição ${ }^{23}$.

O fato é que na denominada “fase legalista do Estado" o abuso do monarca, refletiu em arbitrariedades por parte do legislativo e consequente desconfiança da sociedade, culminando na origem do "Estado Constitucional de Direito”, em que a principal tarefa das Constituições modernas foi de contenção do poder estatal ${ }^{24}$.

Hodiernamente, fala-se no chamado "neoconstitucionalismo", numa passagem do Estado formalmente limitado pela Constituição para um Estado vinculado materialmente a esta, ou seja, na concepção de um sistema jurídico, composto não somente de regras, mas com valores a serem permeados em todo o ordenamento jurídico ${ }^{25}$.

André Estefam e Victor Eduardo Rios Gonçalves ${ }^{26}$, estabelecem como pontos marcantes do neoconstitucionalismo, a saber:

- Estado Constitucional de Direito: superação do Estado Legislativo de Direito, colocando-se a Constituição no centro do sistema, caracterizada por

\footnotetext{
${ }^{23}$ GOMES, Luiz Flávio. Direito Penal: Fundamentos e limites do Direito Penal.p. 310-311.

${ }^{24}$ BARROSO, Luís Roberto. Curso de direito constitucional contemporâneo - os conceitos fundamentais e a construção de um novo modelo. São Paulo: Saraiva, 2009, p. 86.

${ }^{25}$ ESTEFAM, André/GONÇALVES, Victor Eduardo Rios. Direito penal esquematizado: parte geral. 2 ed. rev. e atual. São Paulo: Saraiva, 2013, p. 88. A partir de agora citado apenas como: ESTEFAM, André/GONÇALVES, Victor Eduardo Rios. Direito penal esquematizado: parte geral.

${ }^{26}$ Idem ibidem. p. 89.
} 
intensa carga valorativa, devendo todas as normas serem a partir dela interpretadas;

- Conteúdo axiológico da constituição: o Texto Maior incorpora diversos valores e opções políticas, notadamente a dignidade do ser humano e os direitos fundamentais, que deverão nortear a atividade legislativa;

- Concretização dos valores constitucionais e garantias de condições dignas mínimas: como o norte da atividade dos poderes constituídos.

Neste contexto, é imprescindível para a compreensão do Direito penal, o estudo deste atrelado à Constituição e aos seus valores consagrados, principalmente no que tange aos seus princípios, uma vez que o presente trabalho tem o objetivo o estudo de um princípio constitucional e seus reflexos no âmbito da intervenção penal. Desta forma, no próximo tópico analisaremos os princípios constitucionais penais basilares.

\section{2}

\section{Princípios constitucionais basilares para a compreensão do princípio da insignificância}

A doutrina penal vem apontando alguns princípios constitucionais como “reitores do Direito penal constitucional”27, uns previstos expressamente na Constituição, outros implícitos, pois decorrentes lógicos dos ideais consagrados no texto constitucional, tais como: exclusiva proteção de bens jurídicos ${ }^{28}$, intervenção mínima, legalidade, ofensividade, culpabilidade, insignificância ${ }^{29}$, etc. Desta forma, neste tópico iremos focar nos princípios que entendemos ser imprescindíveis para a compreensão do tema em estudo.

Primeiramente, é importante analisarmos as funções dos princípios no ordenamento jurídico. A doutrina vem apontando cinco funções para os princípios: fundamentadora, interpretativa, supletiva, argumentativa e prospectiva $^{30}$.

\footnotetext{
${ }^{27}$ GOMES, Luiz Flávio. Direito Penal: Fundamentos e limites do Direito Penal. P. 53.

${ }^{28}$ Tratamos deste princípio especificamente como "missão do direito penal”, conforme tópico anterior.

${ }^{29}$ Como trata-se de tema principal do trabalho, será tratado em capítulo próprio.

${ }^{30}$ SILVA, Ivan. Princípio da insignificância. p. 54-55.
} 
Em relação à função fundamentadora, significa que os princípios, pela carga axiológica e a aproximação dos valores importantes para a sociedade, servem como base para todo o ordenamento, dando legitimidade a todo ordenamento, bem como excluindo normas contrárias ao ideais consagrados neles $^{31}$.

Como função interpretativa, entende-se que os princípios servem como vetores de orientação ao aplicador da lei prestando um auxílio para a aplicação das normas, de forma que estas devem estar em consonância com as normas constitucionais e infraconstitucionais. Desta forma, este papel é imprescindível para a compreensão do tema do presente trabalho, uma vez que vislumbramos o princípio da insignificância como um vetor inexorável na interpretação das normas penais incriminadoras.

Ao falarmos de função supletiva dos princípios, é dizer que estes possuem o papel de integrar o ordenamento, diante de lacunas apresentadas em determinadas matérias ${ }^{32}$.

Em relação à função argumentativa, significa dizer que princípios determinam realização de tarefas a serem realizadas na maior medida do possível, ou seja, podem auxiliar no equacionamento de ponderação com outros princípios, tendo em vista que permite que um caso seja solucionado com um princípio determinado preponderando, sem que isto signifique uma violação ao ordenamento $^{33}$. Neste ponto, a compreensão é necessária no sentido de se analisar que é possível a não aplicação do princípio da insignificância em determinados casos em que ocorrer ponderação com outros princípios, sem que isso importe em negativa de vigência do referido princípio.

\footnotetext{
31 SARMENTO, Daniel. A ponderação de interesses na Constituição Federal. Rio de Janeiro: Lumen Juris, 2000, p. 54.

${ }^{32}$ CANOTILHO, José Joaquim Gomes. Direito Constitucional. 6. Ed. Coimbra: Almedina, 1993, p. 167.

33 ESTEFAM, André/GONÇALVES, Victor Eduardo Rios. Direito penal esquematizado: parte geral, p. 97.
} 
Por fim, em relação à função prospectiva, significa que os princípios impedem o retrocesso social em relação aos valores positivos já consagrados pelo ordenamento jurídico.

Assim, após uma análise do papel desempenhado pelos princípios no ordenamento, bem como a compreensão dos pontos marcantes do chamado “neoconstitucionalismo”, no entendimento de que estes irradiam valores em todo ordenamento jurídico, sendo imprescindíveis para a realização da atividade interpretativa, passaremos a analisar os princípios que julgamos basilares para uma adequada compreensão do princípio da insignificância.

\subsection{1}

\section{Princípio da dignidade da pessoa humana}

Imprescindivelmente, temos que iniciar uma explanação sobre princípios basilares do Direito penal, com aquele que a doutrina julga como o mais importante deles, e não é por menos que está inserido no art. $1^{\circ}$ da Constituição, como fundamento da República. De forma que Canotilho observa que este princípio coloca o "indivíduo como limite e fundamento do domínio político da República. Neste sentido, a República é uma organização política que serve o homem, não é o homem que serve os aparelhos político-organizatórios”34.

Embora o alto nível de abstração do princípio em tela, a doutrina aponta dois aspectos de influência do princípio da dignidade da pessoa humana no Direito penal, quais sejam: a proibição de incriminação de condutas socialmente inofensivas e vedação de tratamento degradante no que diz respeito à imposição de sanções ${ }^{35}$.

No primeiro aspecto, vislumbramos que o princípio em tela também funcionará como princípio fundamentador do princípio da insignificância,

\footnotetext{
${ }^{34}$ CANOTILHO, José Joaquim Gomes. Direito Constitucional. 7. Ed. Lisboa: Almedina, 2003, p. 225.

${ }^{35}$ ESTEFAM, André/GONÇALVES, Victor Eduardo Rios. Direito penal esquematizado: parte geral, p. 101.
} 
excluindo da tutela penal condutas incapazes de abalar o convívio social ou de periclitar os bens jurídicos mais importantes.

Cabe ressaltar, por fim, que o princípio em tela tem sido utilizado como vetor para o Supremo Tribunal Federal para resolver diversos casos no âmbito de intervenção penal, inclusive, atrelando o princípio da dignidade da pessoa humana com o princípio da insignificância, senão vejamos:

EMENTA: HABEAS CORPUS. PENAL MILITAR. USO DE SUBSTÂNCIA ENTORPECENTE. PRINCÍPIO DA INSIGNIFICÂNCIA. APLICAÇÃO NO ÂMBITO DA JUSTIÇA MILITAR. ART. $1^{\circ}$, III DA CONSTITUIÇÃO DO BRASIL. PRINCÍPIO DA DIGNIDADE DA PESSOA HUMANA.

1. $\quad$ Paciente, militar, preso em flagrante dentro da unidade militar, quando fumava um cigarro de maconha e tinha consigo outros três.

2. $\quad$ Condenação por posse e uso de entorpecentes. Não-aplicação do princípio da insignificância, em prol da saúde, disciplina e hierarquia militares.

3. A mínima ofensividade da conduta, a ausência de periculosidade social da ação, o reduzido grau de reprovabilidade do comportamento e a inexpressividade da lesão jurídica constituem os requisitos de ordem objetiva autorizadores da aplicação do princípio da insignificância.

4. $\quad$ A Lei n. 11.343/2006 --- nova Lei de Drogas --- veda a prisão do usuário. Prevê, contra ele, apenas a lavratura de termo circunstanciado. Preocupação, do Estado, em mudar a visão que se tem em relação aos usuários de drogas.

5. Punição severa e exemplar deve ser reservada aos traficantes, não alcançando os usuários. A estes devem ser oferecidas políticas sociais eficientes para recuperá-los do vício.

6. $\quad$ O Superior Tribunal Militar não cogitou da aplicação da Lei n. 11.343/2006. Não obstante, cabe a esta Corte fazê-lo, incumbindo-lhe confrontar o princípio da especialidade da lei penal militar, óbice à aplicação da nova Lei de Drogas, com o princípio da dignidade humana, arrolado na Constituição do Brasil de modo destacado, incisivo, vigoroso, como princípio fundamental (art. $1^{\circ}$, III).

7. Paciente jovem, sem antecedentes criminais, com futuro comprometido por condenação penal militar quando há lei que, em vez de apenar --- Lei n. 11.343/2006 --- possibilita a recuperação do civil que praticou a mesma conduta.

8. $\quad$ Exclusão das fileiras do Exército: punição suficiente para que restem preservadas a disciplina e hierarquia militares, indispensáveis ao regular funcionamento de qualquer instituição militar.

9. A aplicação do princípio da insignificância no caso se impõe, a uma, porque presentes seus requisitos, de natureza objetiva; a duas, em virtude da dignidade da pessoa humana.

Ordem concedida ${ }^{36}$ (grifo nosso).

${ }^{36}$ HC 92.961, Rel. Min. Eros Grau, julgamento em 11.12.2007, 2a Turma, DJe 22.02.2008. Cabe ressaltar que recentemente o Plenário do STF entendeu pela inaplicabilidade do princípio da insignificância nos casos de uso de drogas em estabelecimentos militares, conforme HC 94.685, Rel. Min. Ellen Gracie, julgamento em 11.11.2010, Plenário, noticiado no Informativo STF, n. 608. 
No caso supracitado, sob a ótica da função interpretativa dos princípios, podemos observar que a Corte Suprema, analisou o caso sob a ótica de alguns princípios constitucionais, tais como: o da dignidade da pessoa humana, intervenção mínima, ofensividade ou lesividade e insignificância, de modo que fica comprovada a imprescindibilidade da compreensão dos princípios penais para a realização adequada da atividade hermenêutica.

\section{2 .2}

\section{Princípio da intervenção mínima}

Primeiramente, cabe salientar que uma discussão sobre limites do direito penal passa, necessariamente, por uma discussão sobre o modelo de Estado adotado, tendo em vista que num modelo de Estado autoritário, por exemplo, o direito penal não encontra barreiras ${ }^{37}$.

A Constituição Federal de 1988 ao colocar como núcleo os direitos e garantias fundamentais do cidadão, entre eles a dignidade humana, proclamou um estado liberal fundado nas liberdades individuais do cidadão em face do Estado.

Conforme observa João Paulo Orsini Martinelli,

o liberalismo, como doutrina de respeito à autonomia individual, pode e deve, em opinião aqui sustentada, influenciar o direito, uma vez que as normas jurídicas devem atender aos clamores da restrição mínima e suficiente da liberdade. Desse modo, o liberalismo jurídico (legal liberalism) pode ser a orientação para o processo de criminalização de condutas realmente lesivas e ofensivas a interesses alheios ou a interesses de pessoas incapazes de consentir sobre a disposição dos próprios bens. O liberal compreende o direito penal como instrumento a ser usado em casos extremos ${ }^{38}$.

O núcleo do liberalismo sempre foi o respeito às liberdades individuais e a intervenção mínima do Estado. Em que pese, à evolução do liberalismo em relação à figura do Estado neutro, principalmente, no que tange à busca da

${ }^{37}$ MARTINELLI, João Paulo Orsini. Paternalismo jurídico-penal. Tese de Doutorado. São Paulo:

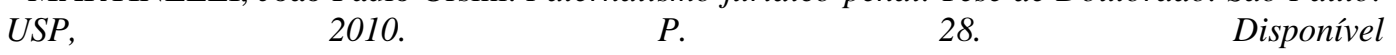
em:www.teses.usp.br/teses/disponiveis/2/2136/tde.../TESE_versao_final.pdf. A partir de agora citado apenas como MARTINELLI, João Paulo Orsini. Paternalismo jurídico-penal.

${ }^{38}$ MARTINELLI, João Paulo Orsini. Paternalismo jurídico-penal. p. 29. 
igualdade material, a intervenção penal, por ser a forma mais drástica de intervenção estatal, deve ser sempre subsidiária e fragmentária.

A subsidiariedade do Direito penal, diz respeito à intervenção penal em abstrato, vale dizer, significa que o direito penal é o último recurso de intervenção estatal, ou seja, só se criminaliza uma conduta quando os demais ramos do direito não são suficientes para resolver o conflito social instaurado.

Acerca do caráter subsidiário do Direito penal, Roxin assevera que:

A proteção de bens jurídicos não se realiza só mediante o Direito Penal, senão nessa missão cooperam todo o instrumental do ordenamento jurídico, O Direito Penal é, inclusive, a última dentre todas as medidas protetoras que devem ser consideradas, quer dizer que somente se pode intervir quando falhem outros meios de solução social do problema - como a ação civil, os regulamentos de polícia, as sanções não penais, etc. Por isso se denomina a pena como a 'ultima ratio da política social' e se define sua missão como proteção subsidiária de bens jurídicos ${ }^{39}$.

Por outro lado, a fragmentariedade do Direito penal, se refere à intervenção em concreto do Direito penal, determinando que somente os ataques relevantes aos bens jurídicos mais importantes merecem a tutela penal ${ }^{40}$.

Na lição de Muñoz Conde,

nem todas as ações que atacam bens jurídicos são proibidas pelo Direito Penal, nem tampouco todos os bens jurídicos são protegidos por ele. O Direito penal, repito mais uma vez, se limita somente a castigar as ações mais graves contra os bens jurídicos mais importantes, daí seu caráter 'fragmentário', pois que de toda a gama de ações proibidas e bens jurídicos protegidos pelo ordenamento jurídico, o Direito Penal só se ocupa de uma parte, fragmentos, se bem que da maior importância ${ }^{41}$.

O princípio da insignificância é um desdobramento da característica da fragmentariedade do princípio da intervenção mínima, por isso ser imprescindível a noção do modelo de Estado adotado pela nossa Constituição para uma correta

\footnotetext{
${ }^{39}$ ROXIN, Claus. Derecho penal - parte general. Madrid: Civitas, 1997, p. 65.

${ }^{40}$ GOMES, Luiz Flávio. Direito Penal: Fundamentos e limites do Direito Penal. P. 311.

${ }^{41}$ MUÑOZ CONDE. Francisco. Introducciónalderecho penal. Barcelona: Bosch. 1975, p. 71-72.
} 
compreensão do tema e seus fundamentos, pois o princípio da intervenção mínima é inerente ao modelo de Estado liberal social e democrático de Direito.

\section{2 .3}

\section{Princípio da materialização do fato}

De acordo com o princípio em tela, a intervenção penal deve estar atrelada a fatos associados às respectivas sanções, vale dizer, ninguém pode ser punido por o que pensa ou pela ideologia ou modo de viver e sim pela conduta (ação ou omissão) voluntariamente externada, pois o "homem delinque enquanto é, senão enquanto obra”42. Desta forma, não se admite um Direito penal do autor, mas somente um Direito penal do fato.

O fato é que Direito penal voltado para o autor é historicamente o da Alemanha nazista, de modo em que o agente não era punido pelos atos praticados e sim pelo que era, algo totalmente inconcebível num Estado constitucional e humanista de Direito ${ }^{43}$.

Acerca do princípio em tela, Luiz Flavio Gomes observa que

O princípio da materialização do fato, por conseguinte, é inseparável das exigências mais elementares da segurança jurídica, do princípio da igualdade e do postulado ou dogma da exclusiva proteção de bens jurídicos, como missão prioritária do Direito penal (...) oferece ao operador jurídico um critério (melhor que qualquer outro) que possibilita a aplicação igualitária do Direito. O princípio da materialização do fato iguala, equipara, uniformiza a reação penal em seus pressupostos e fundamentos, de acordo com as exigências constitucionais do nosso Estado constitucional e humanista de Direito. Só o respeito escrupuloso do princípio da materialização do fato garante a efetiva igualdade diante da lei (CF; art. $5^{\circ}$ ) e impede a arbitrariedade, o despotismo e a injustiça dos sistemas que dão prioridade à pessoa do autor no momento de ponderar a resposta do Estado (...) expressa o pressuposto mínimo exigível à intervenção penal do Estado, já que esta não se legitima sem a lesão ou o perigo que, pelo menos, o fato cometido representa ${ }^{44}$.

\footnotetext{
${ }^{42}$ ANTÓN ONECA, José. Derecho penal: parte general. 2. Ed. Madrid: Akal, 1986, p. 159.

${ }^{43}$ MASSON, Cleber Rogério. Direito penal esquematizado: parte geral - vol. 1. $5^{\mathrm{a}}$ ed. São Paulo: Método, 2011, p. 47.

${ }^{44}$ GOMES, Luiz Flávio. Direito Penal: Fundamentos e limites do Direito Penal. P. 332.
} 
A adequada compreensão deste princípio irá nos auxiliar na discussão da aplicação do princípio da insignificância nos casos envolvendo criminosos contumazes.

\title{
1.2.4
}

\section{Princípio da legalidade}

Trata-se de princípio basilar e previsto expressamente tanto no Código Penal, quanto na Constituição que prescreve no art. 5, inciso XXXIX que "não há crime sem lei anterior que o defina, nem pena sem prévia cominação legal”, ou seja, no Direito penal se tolera tudo que não for expressamente proibido.

É por meio da lei que o Estado concebe ao cidadão a garantia jurídica de não ser sancionado, salvo se existir previsão legal expressa definindo a conduta externada voluntariamente por ele.

Ocorre que em um Estado Constitucional de Direito, não basta que se atenda a uma legalidade de cunho formal, ou seja, que apenas se atente às formas e procedimentos previstos na Constituição, mas principalmente, que o conteúdo da norma esteja de acordo com os princípios, normas e valores consagrados na ordem constitucional (legalidade material) ${ }^{45}$.

\begin{abstract}
Neste contexto, Ferrajoli orienta que
O sistema das normas sobre a produção de normas - habitualmente estabelecido, em nossos ordenamentos, com fundamento constitucional - não se compõe somente de normas formais sobre a competência ou sobre os procedimentos de formação das leis. Inclui também normas substanciais, como o princípio da igualdade e os direitos fundamentais, que de modo diverso limitam e vinculam o poder legislativo excluindo ou impondo-lhe determinados conteúdos. Assim, uma norma - por exemplo, uma lei que viola o princípio constitucional das igualdade - por mais que tenha existência formal ou vigência, pode muito bem ser inválida e como tal suscetível de anulação por contraste com uma norma substancial sobre sua produção ${ }^{46}$.
\end{abstract}

\footnotetext{
${ }^{45}$ GRECO, Rogério. Curso de Direito Penal parte geral.9 ed. Rio de Janeiro: Impetus, 2007. p. 99.

${ }^{46}$ FERRAJOLI, Luigi. Derechos y garantias - La ley Del más débil. Madrid: Trotta, 2001, p. 2021.
} 
Assim, é importante dizer que o princípio da legalidade não determina a punição da conduta somente por esta estar prevista num tipo penal incriminador, pois a atividade interpretativa do operador do Direito deve estar atrelada não apenas à existência da norma penal, mas na análise da conduta sob o ponto de vista de todos os princípios e normas jurídicas consagradas na Constituição.

\section{2 .5}

\section{Princípio da proporcionalidade}

A proporcionalidade é desdobrada na tríade: adequação (medida correta para atingir os fins desejados pela norma), necessidade (utilização do meio menos gravoso para atingir a finalidade) e proporcionalidade em sentido estrito (comparação da ofensa praticada com a sanção imposta) ${ }^{47}$.

Sobre o tema, Alberto Silva Franco leciona que

O princípio da proporcionalidade exige que se faça um juízo de ponderação sobre a relação existente entre o bem que é lesionado ou posto em perigo (gravidade do fato) e o bem de que pode alguém ser privado (gravidade da pena). Toda vez que, nessa relação, houver um desequilíbrio acentuado, estabelece-se, em consequencia, inaceitável desproporção. O princípio da proporcionalidade rechaça, portanto, o estabelecimento de cominações legais (proporcionalidade em abstrato) e a imposição de penas (proporcionalidade em concreto) que careçam de relação valorativa com o fato cometido considerado em seu significado global. Tem, em consequência, um duplo destinatário: o poder legislativo (que tem de estalebecer penas proporcionadas, em abstrato, à gravidade do delito) e o juiz (as penas que os juízes impõem ao autor do delito têm de ser proporcionadas à sua

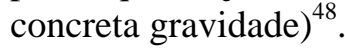

Cabe salientar que o Supremo Tribunal Federal entendeu no julgamento da ADI 3112, em que declarou a inconstitucionalidade da vedação da liberdade provisória no estatuto do desarmamento que o princípio da proporcionalidade seria decorrente do princípio do devido processo legal em seu caráter substantivo $^{49}$. Desta forma, entendeu não ser proporcional equiparar os delitos no referido estatuto ao tratamento dado aos crimes hediondos e equiparados.

47 ESTEFAM, André/GONÇALVES, Victor Eduardo Rios. Direito penal esquematizado: parte geral, p. 144-145.

${ }^{48}$ SILVA FRANCO, Alberto. Crimes hediondos. 4. Ed. São Paulo: Revista dos Tribunais, 1997, p. 67.

${ }^{49}$ ADI 3112, Rel. Min. Ricardo Lewandowski, Informativo 465, STF. 
Neste ponto, vislumbramos que quando o princípio da proporcionalidade exige uma análise entre a gravidade da conduta praticada e a sanção imposta, fundamentando a aplicação do princípio da insignificância, de modo que, em relação às condutas ínfimas, a intervenção penal se mostra desproporcional e desnecessária.

Neste sentido é a lição de Odone Sanquiné, a saber:

O fundamento do princípio da insignificância está na idéia de 'proporcionalidade' que a pena deve guardar em relação à gravidade do crime. Nos casos de ínfima afetação ao bem jurídico, o conteúdo de injusto é tão pequeno que não subsiste nenhuma razão para o pathos ético da pena. Ainda a mínima pena aplicada seria desproporcional à significação social do fato ${ }^{50}$.

\subsection{6}

\section{Princípio da lesividade ou ofensividade}

O princípio em tela exige, para a configuração de um crime, que a conduta praticada seja capaz de causar lesão ou perigo de lesão concreto ao bem jurídico tutelado e é conhecida pelo brocardo latim nullum crimen sine injuria. Desta forma, questiona-se a constitucionalidade dos crimes de perigo abstrato, por exemplo, a direção de veículo automotor sem habilitação, no entanto, a doutrina e jurisprudência majoritária tem permitido ao legislador incriminar condutas que a experiência prática revelam ser perigosas ${ }^{51}$.

Segundo Nilo Batista ${ }^{52}$, o princípio em tela possui quatro funções: a) proibir a incriminação de uma atitude interna; b) proibir a incriminação de uma conduta que não exceda o âmbito do próprio autor (para alguns está ligado ao princípio da alteridade ${ }^{53}$ ); c) proibir a incriminação de simples estados ou condições existenciais (para alguns está ligado ao princípio da materialização do

50 SANGUINÉ, Odone. Observações sobre o princípio da insignificância. Fascículos de Ciências Penais. Porto Alegre: Sergio Antonio Fabris, ano 3, v.3, n. 1, jan./mar./1990, p. 47. A partir de agora citado apenas comoSANGUINÉ, Odone. Observações sobre o princípio da insignificância. ${ }^{51}$ ESTEFAM, André/GONÇALVES, Victor Eduardo Rios. Direito penal esquematizado: parte geral, p. 134-135.

${ }^{52}$ BATISTA, Nilo. Introdução crítica ao direito penal brasileiro. Rio de Janeiro: Revan, 1996, p. 92-94.

${ }^{53}$ GUSTAVO, Junqueira/VANZOLINI, Patrícia. Manual de direito penal. São Paula: Saraiva, 2013, p. 39. 
fato $^{54}$ ); d) proibir a incriminação de condutas desviadas que não afetem qualquer bem jurídico.

Com base no princípio em tela o Supremo Tribunal Federal já entendeu ser excluída do âmbito da intervenção penal a conduta de portar arma de fogo desmuniciada ${ }^{55}$.

Em síntese, o princípio em tela possui dois destinatários: o legislador, que está impedido de criar tipos penais que não representem ofensividade concreta e o aplicador da norma, de modo a não se considerar típica materialmente a conduta incapaz de lesão ou periclitar de forma efetiva o bem jurídico tutelado ${ }^{56}$.

O princípio em tela, assim como o princípio da insignificância, exerce o papel de princípio reducionista da atividade punitiva do Estado, exigindo do aplicador da norma um juízo de desvaloração da conduta e do resultado jurídico. E para Luiz Flávio Gomes, este resultado jurídico só será considerado desvalioso quando:

a) real ou concreto (em virtude do princípio da ofensividade está proibido no Direito penal o perigo abstrato) (...); b) transcendental (afetação de terceiros princípio da alteridade); c) grave (resultado insignificante está regido pelo princípio da insignificância); d) intolerável; e) objetivamente imputável ao risco criado (pela conduta) e g) pertencente ao âmbito de proteção da norma ${ }^{57}$.

Neste ponto, também entendermos ser necessária uma correta distinção entre os princípios da ofensividade e da insignificância, sendo que em relação a ofensividade, a conduta será excluída do âmbito de incidência do direito penal, por ser incapaz de causar uma real ou concreta lesão ou perigo de lesão ao bem jurídico tutelado, ao passo que na insignificância, a conduta ou resultado lesam ou expõe a perigo o bem jurídico tutelado, mas não de forma grave ou intolerável, sendo desproporcional a intervenção penal. No próximo tópico analisaremos em qual momento deverá ser feita a análise da incidência ou não, dos princípios em tela.

\footnotetext{
${ }^{54}$ GOMES, Luiz Flávio. Direito Penal: Fundamentos e limites do Direito Penal. P. 332.

${ }^{55}$ HC.449, Rel. Ellen Gracie. Julgamento em 11/02/2010, 2a Turma, DJe 027.

56 GUSTAVO, Junqueira/VANZOLINI, Patrícia. Manual de direito penal. São Paulo: Saraiva, 2013, p. 39.

${ }^{57}$ GOMES, Luiz Flávio. Direito Penal: Fundamentos e limites do Direito Penal. P. 383.
} 


\section{3}

\section{A evolução do conceito analítico de crime: alocação da análise da insignificância na teoria no crime}

Neste tópico iremos analisar o conceito analítico de crime, visando demonstrar onde se encontra alojado, dentro da teoria do crime, o estudo sobre o princípio da insignificância, pois isso será imprescindível para entendermos a natureza jurídica do princípio em tela.

O fato é que, podemos extrair da doutrina três concepções de crime: material, formal e analítica. Sob a perspectiva material, crime é toda conduta, consciente e voluntária, prevista em lei, que lesa ou expõe a perigo bens jurídicos indispensáveis ao convívio social; sob o aspecto formal, crime é toda conduta prevista em norma penal incriminadora; sob a concepção analítica, crime é fato típico, antijurídico ou ilícito e culpável ${ }^{58}$.

Desta forma, embora crime seja um todo unitário, a doutrina penal, para um melhor estudo da infração penal, passou a realizar uma análise sistemática sobre cada elemento componente da infração penal, sendo por isso chamado de conceito analítico ou estratificado de crime.

Nas lições de Claus Roxin,

quase todas as teorias do delito até hoje construídas são sistemas de elementos, isto é, elas dissecam o comportamento delitivo em um número de diferentes elementos (objetivos, subjetivos, normativos, descritivos, etc.), que são posicionados nos diversos estratos da construção do crime, constituindo algo como um mosaico do quadro legislativo do fato punível. Esta forma de proceder acaba levando a que se votem grandes esforços à questão sobre que posicionamento no sistema do delito deve ocupar esta ou aquela elementar do crime; pode-se descrever a história da teoria do delito nas últimas décadas como uma migração de elementares do delito entre diferentes andares do sistema ${ }^{59}$.

\footnotetext{
58 ESTEFAM, André/GONÇALVES, Victor Eduardo Rios. Direito penal esquematizado: parte geral, p. 268.

59 ROXIN, Claus, Política criminal e sistema jurídico-penal. Trad. Int.de Luís Greco. Rio de Janeiro: Renovar, 2000, p. 85-86.
} 
Neste contexto, de acordo com a doutrina majoritária, crime é constituído dos substratos chamados de: fato típico, ilicitude ou antijuridicidade e culpabilidade e, possui como consequência, a punibilidade ${ }^{60}$.

No presente trabalho o foco será sobre o fato típico, mais precisamente sob a tipicidade, uma vez que aqui é que terá incidência o princípio da insignificância. Neste ponto, cabe salientar que o fato típico é formado por quatro elementos: conduta, nexo de causalidade, resultado e tipicidade. Buscando ser breve e objetivo, temos que conduta, segundo a teoria finalista, seria a ação humana voluntária psiquicamente dirigida a um fim; nexo de causalidade, seria a relação entre a conduta e o resultado, sem a qual o mesmo não teria ocorrido; resultado, seria a relevante lesão ou perigo de lesão ao bem jurídico tutelado e, por fim, temos a tipicidade que, antigamente, se restringia à mera subsunção do fato ao tipo penal incriminador.

O movimento denominado funcionalista surgiu no direito penal como teoria proposta em contrapartida às teorias ditas positivistas as quais propunham um estudo isolado ou ontológico do direito penal.

Neste contexto, o funcionalismo racional proposto por Claus Roxin consiste em superar as barreiras existentes entre o Direito Penal e a Política criminal, visando a construção de um sistema apto para resolver os problemas da sociedade $^{61}$. O próprio Roxin coloca como objetivo de seu estudo a superação do contrassenso do positivismo jurídico o qual apresentava um tecnicismo impecável, mas não resolvia adequadamente os problemas sob o ponto de vista político criminal $^{62}$.

O fato é que não há como o legislador, ao selecionar todos os fatos humanos indesejados que mereceram a intervenção do direito penal, prever e inserir na norma todas as circunstâncias ou graus de lesão para a incidência do

${ }^{60}$ CIRINO DOS SANTOS, Juarez. A moderna teoria do fato punível. Rio de Janeiro: Freitas Bastos, 2001, p. 5.

${ }^{61}$ SILVA SANCHES, Derecho penal contemporaneo, p. 69.

${ }^{62}$ ROXIN, Claus, Política criminal e sistema jurídico-penal. Trad. Int.de Luís Greco. Rio de Janeiro: Renovar, 2000, p. 33. 
tipo penal. Desta forma, esta tarefa valorativa da incidência do tipo penal, ficou a cargo do aplicador da lei.

Ocorre que, Claus Roxin, buscando evitar a expansão das condutas incriminadoras e adequar o direito penal aos princípios de política criminal, passou a defender que cada uma das categorias do delito devem ser estudadas sob esta ótica, ou seja, com base em tais princípios ${ }^{63}$. Assim, no âmbito da tipicidade, por exemplo, defende que ela possui uma dimensão formal, em que se analisa apenas à subsunção do fato à norma (ex.: João subtraiu um bombom de um supermercado, logo, esta conduta se ajusta ao tipo penal descrito no art. 155 do Código Penal, possuindo tipicidade formal ${ }^{64}$ ) e uma dimensão material, em que será valorado se a conduta e/ou resultado causou relevanteeintolerável lesão ou perigo de lesão ao bem jurídico tutelado (a conduta perpetrada foi capaz de lesar significativamente o patrimônio do supermercado?) e é neste ponto em que se encontra inserido a atuação do princípio da insignificância, o qual excluirá a tipicidade na sua dimensão material.

${ }^{63}$ GOMES, Luiz Flávio. Direito Penal: Fundamentos e limites do Direito Penal. p. 619.

64 “Subtrair coisa alheia móvel para si ou para outrem”. 


\section{2 \\ O princípio da insignificância sob uma perspectiva constitucional}

Neste capítulo iremos intensificar a análise sobre o tema principal do trabalho que é o princípio da insignificância.

Desta forma, faremos uma explanação sobre os vários aspectos do princípio em tela, com conceito, origem, natureza jurídica e analisar a quem incumbe a aplicação do princípio em tela.

\section{1}

Conceito, origem, previsão legal e natureza jurídica

Para uma melhor organização e entendimento, iremos subdividir o tópico em tela.

\subsection{1}

Conceito

Entre as várias resistências que o instituto em tela possui no mundo jurídico, uma dela se refere à ausência de um conceito legal em relação ao princípio da insignificância, sendo que a definição de critérios para a aplicação, bem como o estabelecimento do que seria insignificante ou não, fica a critério do aplicador da norma e suas concepções. Desta forma, alguns alegam que esta indeterminação gera risco à segurança jurídica ${ }^{65}$.

O fato é que, conforme já explanamos acima, não há como o legislador, ao selecionar todos os fatos humanos indesejados que mereceram a intervenção do direito penal, prever e inserir na norma todas as circunstâncias ou graus de lesão para a incidência do tipo penal, assim como não há como estabelecer todas as

${ }^{65}$ SILVA, Ivan. Princípio da insignificância. p. 99. 
circunstâncias e graus de proporção que se entende por legítima defesa, e nem por isso a aplicação de tal excludente é questionada. Desta forma, é no direito que a lei não seja capaz de exaurir todas as situações de forma que é imprescindível que certas tarefas fiquem a cargo do operador do direito e é justamente para isso que existem os princípios, de forma a auxiliar o intérprete a realizar esta atividade valorativa.

No entanto, embora a discussão sobre a falta de uma definição legal, a doutrina e jurisprudência tem fixado conceitos para o princípio em tela, o que de certa forma, encerra o embate sobre a falta de segurança jurídica, tendo em vista que também se mostram como fontes do direito.

Luiz Flávio Gomes, cita as lições de Abel Cornejo, para qual o princípio da insignificância

é o que permite não processar condutas socialmente irrelevantes, assegurando não só que a Justiça esteja mais desafogada, ou bem menos assoberbada, senão permitindo também que fatos nímios não se transformem em uma sorte de estigma para seus autores. Do mesmo modo, abre a porta para uma revalorização do direito constitucional e contribui para que se imponham penas a fatos que merecem ser castigados por seu alto conteúdo criminal, facilitando a redução dos níveis de impunidade. Aplicando-se este princípio a fatos nímios se fortalece a função da Administração da Justiça, porquanto deixa de atender a fatos mínimos para cumprir seu verdadeiro papel. Não é um princípio de direito processual, senão de Direito penal ${ }^{66}$.

Diomar Ackel conceitua o princípio da insignificância como aquele que

Permite infirmar a tipicidade de fatos que, por sua inexpressividade, constituem ações de bagatela, desprovida de reprovabilidade, de modo a não merecerem valoração da norma penal, exsurgindo, pois, como irrelevantes. A tais ações, falta o juízo de censura penal ${ }^{67}$.

Por outro lado, Ivan Luiz da Silva o conceitua como sendo o princípio que

\footnotetext{
${ }^{66}$ GOMES, Luiz Flávio. Princípio da insignificância e outras excludentes de tipicidade. 3 ed. rev. atual. eampl. São Paulo: RT, 2013. pp. 51-52. A partir de agora citado apenas como: GOMES, Luiz Flávio. Princípio da insignificância.

${ }^{67}$ ACKEL FILHO, Diomar. O princípio da insignificância no direito penal. Revista de Jurisprudência do Tribunal de Alçada de São Paulo. São Paulo: TJSP, v. 94, p. 72-77, abr./jun./1988. A partir de agora citado apenas como ACKEL FILHO, Diomar. O princípio da insignificância no direito penal.
} 
Interpreta restritivamente o tipo penal, aferindo qualitativa e quantitativamente o grau de lesividade da conduta, para excluir da incidência penal os fatos de poder ofensivo insignificante aos bens jurídicos penalmente protegidos ${ }^{68}$.

Dentro da jurisprudência também podemos aferir alguns conceitos sobre o princípio em tela, senão vejamos:

O princípio da insignificância pode ser conceituado como aquele que permite desconsiderar-se a tipicidade de fatos que, por sua inexpressividade, constituem ações de bagatelas, afastadas do campo da reprovabilidade, a ponto de não merecerem maior significado aos termos da norma penal, emergindo, pois, a completa falta de juízo de reprovação penal ${ }^{69}$.

Sendo favoráveis as condições pessoais do agente, é aplicável o princípio da insignificância em relação à conduta que, subsumida formalmente ao tipo correspondente ao furto simples (art. 155, caput, do CP), consista na subtração de bem móvel de valor equivalente a pouco mais de $23 \%$ do salário mínimo vigente no tempo do fato. Nessa situação, ainda que ocorra a perfeita adequação formal da conduta à lei incriminadora e esteja comprovado o dolo do agente, inexiste a tipicidade material, que consiste na relevância penal da conduta e do resultado produzido. Assim, em casos como este, a aplicação da sanção penal configura indevida desproporcionalidade, pois o resultado jurídico - a lesão produzida ao bem jurídico tutelado - há de ser considerado como absolutamente irrelevante ${ }^{70}$.

Nós conceituamos o princípio em estudo como um princípio com uma importante função interpretativa de funcionar como um filtro valorativo do âmbito de incidência do direito penal, excluindo as condutas e/ou resultados incapazes de gerar relevantes lesões ou perigo de lesões aos bens jurídicos tutelados, evitando uma desproporção causada pela intervenção penal a uma conduta ínfima apenas por ser formalmente típica.

No mesmo sentido temos as lições de Carlos Vico Mañas, senão vejamos:

Ao realizar o trabalho de redação do tipo penal, o legislador apenas tem em mente os prejuízos relevantes que o comportamento incriminado possa causar à ordem jurídica e social. Todavia, não dispõe de meios para evitar que também sejam alcançados os casos leves. O princípio da insignificância surge justamente para evitar situações dessa espécie, atuando como instrumento de interpretação restritiva do tipo penal, com o significado sistemático político-criminal da

\footnotetext{
${ }^{68}$ SILVA, Ivan. Princípio da insignificância. p.101.

${ }^{69}$ TACrim-SP, apl. 1.044.889/5, Rel. Breno Guimarães, 24.09.1997.

${ }^{70}$ AgRg no HC 254.651-PE, Rel. Min. Jorge Mussi, 12.3.2013.
} 
expressão da regra constitucional do nullumcrimensine lege, que nada mais faz do que revelar a natureza subsidiária e fragmentária do direito penal ${ }^{71}$.

O chamado “crime insignificante” ou "infração bagatelar” não possui relevância penal ou por ausência de periculosidade da conduta perpetrada ou por irrelevância do resultado jurídico ou ambos. Luiz Flávio Gomes observa que as três situações podem ocorrer e gerar a ausência da incidência penal, por exemplo, aquele que auxilia uma inundação dolosa com um copo d’água não pode ser criminalizado, pois sua ação foi irrelevante, ainda que o resultado tenha sido devastador. Por outro lado, quem subtrai uma caixa de fósforo de um supermercado não deve ser criminalizado, pelo fato do resultado jurídico ter sido irrelevante. E, por fim, exemplifica o caso de um acidente de trânsito por culpa levíssima do condutor e que gera apenas um arranhão em uma vítima, onde teríamos tanto uma conduta irrelevante, quanto o resultado jurídico gerado, o que também não receberia a incidência do direito penal ${ }^{72}$. Desta forma, concluímos que na tipicidade material deverá ocorrer um juízo valorativo sobre a conduta e sobre o resultado jurídico gerado.

\subsection{2 \\ Origem}

Para não esquivarmos das discussões sobre o princípio da insignificância, até mesmo sua origem é controvertida. Para alguns ${ }^{73}$, os humanistas é que construíram o brocardo minima non curatpraetor (o juiz não deve cuidar de questões mínimas). Outros ${ }^{74}$,defendem que tal princípio já existia no Direito romano, onde o pretor não cuidava das causas irrelevantes, invocando o brocardo

\footnotetext{
${ }^{71}$ VICO MAÑAS, Carlos. O princípio da insignificância como excludente da tipicidade no direito penal. São Paulo: Saraiva, 1994, p. 56. A partir de agora citado apenas como VICO MAÑAS, Carlos. O princípio da insignificância como excludente da tipicidade no direito penal.

${ }^{72}$ GOMES, Luiz Flávio. Princípio da insignificância e outras excludentes de tipicidade. $3^{\mathrm{a}}$ ed. rev. atual. eampl.- São Paulo: Editora Revista dos Tribunais, 2013. p. 19.

${ }^{73}$ DALBORA, José Luis Guzmán. La insignificância: especificación y reducción valorativas em El âmbito de lo injusto típico. Revista de Derecho Penal y Criminologia. n. 5. Madrid: UNED, 1995. P. 514 e SS.

74 ACKEL FILHO, Diomar. O princípio da insignificância no direito penal. Revista de Jurisprudência do Tribunal de Alçada de São Paulo. São Paulo: TJSP, v. 94, p. 73, abr./jun./1988.
} 
acima. E, por fim, há os que entendem que o princípio em tela tem origem no Iluminismo, como evolução e desdobramento do princípio da Legalidade ${ }^{75}$.

O fato é que os verdadeiros contornos do princípio em estudo foram dados por Claus Roxin em 1964, reconhecendo a insignificância como causa excludente de tipicidade ${ }^{76}$. Por outro lado, Klaus Tiedmann tratou como sinônima a expressão “Princípio da Bagatela”77.

\subsection{3}

\section{Previsão legal}

Interessante observação é que embora alguns critiquem a aplicação do princípio em tela por ausência de norma expressa, nós podemos observar a adoção normativa do princípio em tela num dos códigos mais repressivos do nosso ordenamento jurídico. O Código penal militar em seu artigo 209, $\S 6^{\circ}$ prescreve que "no caso de lesões levíssimas o juiz pode considerar a infração como disciplinar”, da mesma forma determina o art. 240, $\S 1^{\circ}$ para o furto insignificante $^{78}$.

Da mesma forma, encontramos em legislações de diversos países a disposição expressa sobre o princípio da insignificância, como o Código Penal português, austríaco, cubano, chinês, polonês e alemão ("art. $3^{\circ}$ - não subsiste o crime, se, não obstante a conformidade da conduta à descrição legal de um tipo, as consequências do fato sobre direitos e os interesses dos cidadãos e da sociedade e a culpabilidade do réu são insignificantes”) ${ }^{79}$.

\footnotetext{
${ }^{75}$ LOPES, Mauricio Antonio Ribeiro. Princípio da insignificância no direito penal: análise à luz da Lei 9099/95. São Paulo: RT, 1997. p. 37-38.

${ }^{76}$ GOMES, Luiz Flávio. Princípio da insignificância. p. 54.

${ }^{77}$ CABETTE, Eduardo Luiz Santos. O mito da não existência de previsão legal do princípio da insignificância no Brasil. In: Boletim IBCCRIM ano 21, nº 251, Outubro/2013 - ISSN 1676-3661. P. 16.

${ }^{78}$ CABETTE, Eduardo Luiz Santos. O mito da não existência de previsão legal do princípio da insignificância no Brasil. In: Boletim IBCCRIM ano 21, nº 251, Outubro/2013 - ISSN 1676-3661. P. 16.

${ }^{79}$ Idem ibidem.
} 


\subsection{4}

\section{Natureza jurídica}

Outro fator de grande divergência doutrinária e jurisprudencial se refere à natureza jurídica do princípio da insignificância, ou seja, sua localização no campo da teoria do delito, onde existem quatro correntes: uma que define como causa excludente de tipicidade, outra como excludente de antijuridicidade, uma terceira como excludente de culpabilidade e uma quarta como natureza ubíqua (excludente de tipicidade/antijudicidade). Desta forma, iremos analisar o defendido por cada uma dessas correntes.

\subsubsection{1}

\section{Excludente de antijuridicidade}

Esta corrente coloca o princípio da insignificância como excludente de antijuridicidade material, tendo como defensores na doutrina brasileira Alberto Silva Franco ${ }^{80}$ e Carlos Frederico Pereira ${ }^{81}$.

O argumento é de que o juízo valorativo de relevância ou não da ação ou resultado, deve ser feito no âmbito da antijuridicidade e não no âmbito da tipicidade. Na doutrina chilena, Guzmán Dalbora, observa que esta análise do grau da lesão ao bem jurídico tutelado, deve ser feita sob a ótica da teoria da antijuridicidade, ao menos que seja violada a natureza descritiva do tipo penal ${ }^{82}$.

$\mathrm{Na}$ jurisprudência pátria encontramos alguns poucos julgados que adotam esta natureza jurídica em relação ao princípio em estudo, a saber:

Dentre as lesões inofensivas, às quais não se debita antijuridicidade, está a criminalidade de bagatela. Nesse sentido a jurisprudência tem reconhecido a necessidade de lesividade do ilícito penal, quer em delitos patrimoniais, que em delitos de outra espécie. Tal posicionamento significa um induvidoso reforço à

\footnotetext{
${ }^{80}$ TACrim-SP, Apel. 283.949, Rel. Silva Franco. 23.11.1981.

${ }^{81}$ PEREIRA, Carlos Frederico de O. O conceito de bem jurídico e o princípio da insignificância. Revista do Ministério Público Militar. Brasília: MPM, ano X, n. 13, 1991, p 50.

${ }^{82}$ DALBORA, José Luis Guzmán. La insignificância: especificación y reducción valorativas em El âmbito de lo injusto típico. Revista brasileira de Ciências Criminais. São Paulo: RT, ano 4. n. 14, p. 41-81, abr./jun./1996.
} 
consideração de que não basta que a ação se ajuste formalmente ao tipo, devendo ainda causar lesão significante para caracterizar o crime ${ }^{83}$.

Apesar da manifestação em contrário da maioria da doutrina brasileira, não se pode atribuir ao conceito de antijuridicidade uma conotação exclusivamente formal, quaisquer que sejam os riscos que se insiram nesse posicionamento ${ }^{84}$.

O fato é que as posições acima, se baseiam no conceito dualista (formal e material) de antijudicidade, o qual vislumbra a antijuridicidade como uma conduta humana contrária a todo ordenamento jurídico (sentido formal) e capaz de causar lesão ou expor a perigo de lesão um bem jurídico tutelado (sentido material) ${ }^{85}$.

Ocorre que, a doutrina penal rechaça este conceito dualista de ilicitude ou antijuridicidade, alegando que quando uma norma penal proíbe determinada conduta é porque tal conduta, pelo menos em potencial, é capaz de gerar lesão ou perigo de lesão ao bem jurídico tutelado ${ }^{86}$.

Neste sentido são as lições de Francisco de Assis Toledo em trabalho específico sobre a ilicitude penal, senão vejamos:

Um comportamento humano que se ponha em relação de antagonismo com a ordem jurídica não pode deixar de lesar ou de expor a perigo de lesão os bens jurídicos tutelados por essa mesma ordem jurídica. Isso leva à conclusão de que a ilicitude, tal como a definimos anteriormente, só pode ser uma só, ou seja, aquela que se quer denominar redundantemente de material ${ }^{87}$.

\subsubsection{2}

\section{Excludente de culpabilidade}

Esta corrente, defendida pelo jurista português Abel Cornejo, defende que a falta de proporcionalidade entre o fato insignificante e a sanção penal, torna conveniente o afastamento da pena, pois ausente sua justificação ética, excluindo, pois, a culpabilidade ${ }^{88}$.

\footnotetext{
${ }^{83}$ TACrim-SP, Apel. 783.371/4, Rel. Ary Casagrande. 16.05.1994.

${ }^{84}$ TACrim-SP, Apel. 283.949, Rel. Silva Franco. 23.11.1981.

${ }^{85}$ REALE JÚNIOR, Miguel.Teoria do delito. São Paulo: RT. 1998. p. 91.

${ }^{86}$ GRECO, Rogério. Curso de Direito Penal parte geral.9 ed. Rio de Janeiro: Impetus, 2007. p. 314.

${ }^{87}$ TOLEDO, Francisco de Assis. Ilicitude penal e causas de sua exclusão. Rio de Janeiro: Forense. 1984. p. 8.

${ }^{88}$ CORNEJO, Abel. Teoria de La insignificância. Buenos Aires: Ad Hoc. 1997. P. 72.
} 
No próximo tópico iremos abordar a diferença do princípio da insignificância para o princípio da irrelevância penal do fato (e da desnecessidade da pena), onde será possível visualizar que a desnecessidade da pena está atrelada ao princípio da irrelevância penal do fato e não da insignificância, pois se a conduta e/ou resultado são insignificantes não chegaremos, levando em conta o conceito analítico de crime, até a análise da culpabilidade, de forma que discordamos desta posição.

\subsubsection{3}

\section{Excludente de tipicidade}

A posição em tela é a que encontra mais adeptos seja no campo doutrinário como jurisprudencial. Na doutrina pátria podemos citar como defensores dessa corrente juristas que desenvolveram trabalhos específicos sobre o tema em estudo, tais como: Francisco de Assis Toledo ${ }^{89}$, Diomar Ackel $^{90}$, OdoneSanguiné ${ }^{91}$, Luiz Flávio Gomes ${ }^{92}$ e Carlos Vico Manãs ${ }^{93}$.

Conforme exposto no tópico 2.3 do presente trabalho, ClausRoxin, buscando evitar a expansão das condutas incriminadoras e adequar o direito penal aos princípios de política criminal, passou a defender que cada uma das categorias do delito (conceito analítico de crime) devem ser estudadas sob esta ótica, ou seja, com base em tais princípios ${ }^{94}$. Assim, no âmbito da tipicidade, por exemplo, defende que ela possui uma dimensão formal, em que se analisa apenas à subsunção do fato à norma (ex.: João subtraiu um bombom de um supermercado, logo, esta conduta se ajusta ao tipo penal descrito no art. 155 do Código Penal, possuindo tipicidade formal ${ }^{95}$ ) e uma dimensão material, em que será valorado se a conduta e/ou resultado causou relevante e intolerável lesão ou perigo de lesão ao

89 TOLEDO, Francisco de Assis. Princípios básicos de direito penal. 5 ed. São Paulo: Saraiva. 2000. p. 133.

${ }^{90}$ ACKEL FILHO, Diomar. O princípio da insignificância no direito penal. p. 73.

${ }^{91}$ SANGUINÉ, Odone. Observações sobre o princípio da insignificância. p. 46.

${ }^{92}$ GOMES, Luiz Flávio. Princípio da insignificância. p. 74.

${ }^{93}$ VICO MAÑAS, Carlos. O princípio da insignificância como excludente da tipicidade no direito penal. p. 53.

94 GOMES, Luiz Flávio. Direito Penal: Fundamentos e limites do Direito Penal. P. 619.

95 "Subtrair coisa alheia móvel para si ou para outrem”. 
bem jurídico tutelado (a conduta perpetrada foi capaz de lesar significativamente o patrimônio do supermercado?) e é neste ponto em que se encontra inserido a atuação do princípio da insignificância, o qual excluirá a tipicidade na sua dimensão material.

No âmbito da jurisprudência, o Supremo Tribunal Federal tem se posicionado neste sentido, a saber: “o princípio da insignificância qualifica-se como fator de descaracterização material da tipicidade penal"96.

\subsubsection{4}

\section{Natureza ubíqua (tipicidadelantijuridicidade)}

Ivan Luiz da Silva, em trabalho específico sobre o princípio em tela, defende que o mesmo possui uma natureza jurídica penal ubíqua, pois ora atua como excludente de tipicidade, ora como excludente de ilicitude ou antijuridicidade ${ }^{97}$.

O autor em tela defende que, quando a conduta é insignificante, resultará em exclusão de tipicidade e, quando o resultado for ínfimo, seria caso de exclusão da ilicitude ou antijuridicidade.

Em que pese o brilhante trabalho referido doutrinador, entendemos, como a doutrina e jurisprudência majoritária que, tanto o desvalor da ação, quanto do resultado, deverão ser analisados pelo operador da lei, na análise do fato típico.

\subsection{5}

\section{A quem incumbe a aplicação do princípio da insignificância?}

O tópico em tela, trata-se de outro ponto controvertido, pois, para parte da doutrina, tal análise caberia ao Ministério Público, ao avaliar a possibilidade de

\footnotetext{
96 STF, HC 92.463, Rel. Min. Celso de Mello, julgamento em 16.10.2007, $2^{\text {a }}$ Turma, DJ 31.10.2007.

${ }^{97}$ SILVA, Ivan. Princípio da insignificância. p. 169-171.
} 
oferecer a denúncia ou requerer o arquivamento dos autos do inquérito policial e ao juiz no momento de decidir pelo recebimento ou não da inicial e na sentença ${ }^{98}$.

Embora alguns doutrinadores defendam a impossibilidade do Delegado de Polícia avaliar o fato criminoso sob a ótica da insignificância, é plenamente inconcebível, num Estado Democrático de Direito que se lavre um auto de prisão em flagrante e se submeta ao cárcere alguém por um fato irrelevante para o direito penal. Ademais, o Delegado de Polícia tem uma função de primeiro garantidor dos direitos do cidadão ao realizar a avaliação de legalidade no momento de decidir acerca da ratificação ou não da prisão em flagrante.

Ademais, o art. 283 do Código de Processo Penal prescreve que "ninguém poderá ser preso senão em flagrante delito ou por ordem escrita e fundamentada da autoridade judiciária competente (...)”. Desta forma, imprescindível que exista um delito para a ratificação do auto de prisão em flagrante delito, e, conforme conceito analítico de delito/crime, necessário se faz a presença dos substratos do fato típico, ilicitude e culpabilidade. Assim, o caso em tela impossibilitaria a ratificação do flagrante já pela ausência do primeiro substrato fato típico, no seu elemento tipicidade.

Neste ponto, vale as lições de Roberto Pérez Martinez em tradução livre, Zaccariotto aduz:

No Estado de direito como operador público que é, e por especial atribuição competencial do exercício da violência legal, a polícia deve atuar observando em todo momento as garantias constitucionais previstas para não deixar sem proteção não apenas o indivíduo como também o próprio sistema democrático. Em consequência, a transcendental relevância que a função policial tem nesse desenho constitucional, apenas se justifica quando se trata de assegurar direitos, bens e valores constitucionalmente reconhecidos sobre o fundamento do princípio da legalidade, conforme os critérios da igualdade, necessidade e proporcionalidade $^{99}$.

${ }^{98}$ Cabe observar que, embora seja possível a aplicação do princípio em tela na sentença, julgamos correto é sequer receber uma inicial de um fato ínfimo, não havendo que se movimentar a máquina estatal para um fato irrelevante para o direito penal.

99 ZACCARIOTTO, José Pedro. A Polícia Judiciária no Estado Democrático. Sorocaba: Brasilian Books, 2005, p. 221. 
A única alegação contra a possibilidade da análise da insignificância pelo delegado de polícia seria a supressão da titularidade do Ministério Público em decidir sobre a ação penal pública, com fulcro no art. 129, I, CF. Ocorre que, tal argumento cairá por terra, caso o Delegado de Polícia deixe de ratificar o flagrante, mas instaure o inquérito policial por portaria para que se submeta ao Ministério Público e ao Judiciário uma avaliação sobre a decisão tomada pelo Delegado de Polícia.

\subsection{6}

\section{Utilitarismo como justificativa para o princípio da insignificância}

Neste ponto, utilizaremos a filosofia utilitarista para auxiliar na justificação de aplicação do princípio em tela.

A ideia básica do utilitarismo é a utilização de um cálculo de custo/benefício dos atos praticados, buscando a maximização da felicidade ao maior número de pessoas. Além de algumas outras vertentes existentes do utilitarismo, Tim Mulgam apresenta quatro formas básicas de utilitarismo: o de atos, indireto, de regras e de instituições. O utilitarismo de atos, analisa cada ato isoladamente de forma a buscar a maximização do bem estar; o indireto, analisa uma junção de atos e de seus procedimentos decisórios; o de instituições, prescreve que o utilitarismo é um guia para a conduta pública e não da privada, de forma que a melhor instituição é aquela capaz de produzir o maior bem estar total $^{100}$.

No utilitarismo de regras, ao invés de se analisar o ato ou o conjunto de atos, busca-se encontrar a regra que puder alcançar os melhores resultados para o maior número de pessoas. Conforme observa Martinelli, tal teoria pode ser bem aplicada ao direito penal, senão vejamos:

O utilitarismo de regras é perfeitamente aplicável ao direito penal desde que tenhamos bem definida a utilidade que desejamos e os meios legítimos para alcança-la. A utilidade deve estar estritamente ligada às finalidades e aos

${ }^{100}$ MULGAM, Tim. Utilitarismo: tradução de Fábio Creder. Petrópolis.RJ: Vozes, 2012, p. 162180. 
princípios do direito penal. O crime não pode ser punido por si mesmo, por seu essência, mas sim para alcançar a uma utilidade: aumentar a expectativa na proteção dos interesses sociais ${ }^{101}$.

A norma penal deve ser útil na medida de conceder maior proteção aos bens jurídicos relevantes e limitar a interferência do direito penal, garantindo a restrição da liberdade apenas aos casos extremos. A proteção do bem jurídico a ser tutelado deve valer o custo da movimentação de toda a máquina estatal, bem como de todos os males gerados pela intervenção penal ${ }^{102}$.

Acreditamos que o utilitarismo de regras fundamenta a aplicação do princípio da insignificância uma vez que a internalização desta norma, é mais útil para as finalidades do direito penal de proteção dos bens jurídicos e de restrição da intervenção estatal, de forma que a não aplicação do princípio geraria uma imensa quantidade de ações sobre fatos ínfimos, o que, por sua vez, acarretaria uma ineficácia estatal em relação aos fatos efetivamente relevantes, além das consequências drásticas da intervenção penal serem totalmente desproporcionais em relação às condutas e/ou resultados jurídicos irrelevantes. Pensemos, por exemplo, numa subtração de um bombom numa rede de supermercados, será que a instauração de inquérito policial, ação penal e condenação deste autor seria proporcional ao ato praticado? Uma resposta positiva iria de encontro claramente às finalidades do direito penal. Ademais, uma ação de reparação de danos cíveis resolveria melhor o conflito gerado pela a ação perpetrada por aquele que realizou a subtração.

\section{2}

\section{Princípio da insignificância X princípio da irrelevância penal do fato}

Esta distinção é pouco analisada pela jurisprudência e doutrina pátria, mas será importante para analisarmos a aplicação dos princípios em tela em alguns delitos.

\footnotetext{
101 MARTINELLI, João Paulo Orsini. Paternalismo jurídico-penal. Tese de Doutorado. São

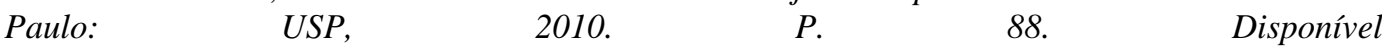
em:www.teses.usp.br/teses/disponiveis/2/2136/tde.../TESE_versao_final.pdf. ${ }^{102}$ Idem Ibidem.
} 
A aplicação do princípio da insignificância se dá nos casos em que o fato já surge como um irrelevante penal, seja pelo fato da conduta perpetrada ser ínfima, seja pelo resultado provocado não expor a perigo o bem jurídico ou em ambos os $\operatorname{casos}^{103}$.

Já o princípio da irrelevância penal do fato, se aplica aos casos que a doutrina denomina de "infrações bagatelares impróprias", em que o fato nasce relevante para o Direito penal, pois a conduta ou o resultado são lesivos, mas, posteriormente, analisando as circunstâncias do fato, personalidade do autor, antecedentes, colaboração com a justiça, etc. entende-se que a pena é desnecessária $^{104}$.

A jurisprudência pátria possui alguns poucos casos de aplicação do princípio da irrelevância penal do fato, os quais serão analisados no próximo tópico.

\footnotetext{
${ }^{103}$ A doutrina usa a expressão "infração bagatelar própria” para denominar estes fatos que já nascem irrelevantes. GOMES, Luiz Flávio. Princípio da insignificância. p. 19.

${ }^{104}$ GOMES, Luiz Flávio. Princípio da insignificância. p. 28-29.
} 


\section{Critérios de aplicação do princípio da insignificância}

Um dos temas mais penosos acerca do princípio da insignificância é sobre os seus critérios de aplicação, ou seja, é extremamente difícil definir o que seria uma conduta ou resultado insignificante. Como a legislação brasileira não traz tais pressupostos, é importante tentar buscar tais fontes na doutrina e jurisprudência.

\section{1}

\section{Critérios de aplicação segundo a doutrina}

A doutrina formulou alguns modelos de critérios para definição do que seria insignificante. Na doutrina brasileira Lycurgo Santos firmou um modelo baseado numa perspectiva ex ante e ex post da conduta típica realizada, a saber:

nos chamados crimes de bagatela o comportamento do agente deve ser visto, sob uma perspectiva ex ante, como pouco relevante para provocar um dano ao bem jurídico protegido pelo Direito Penal; e ex post como definitivamente impróprio para produzir o mencionado dano ${ }^{105}$.

Na doutrina italiana, Carlos Paliero apresentou dois modelos de aferição da conduta insignificante: o clássico, em que se avalia o desvalor da ação, do resultado e da culpabilidade e o baseado na "antecipada comensuração da pena”, em que considera insignificante a conduta apenas quando todos os índices de mensuração da pena estejam mínimos a ponto de se reconhecer que a conduta não deve ser punida ${ }^{106}$.

O doutrinador Vico Mañas ${ }^{107}$, observa que além da mensuração do desvalor da conduta e do resultado, citados no modelo “clássico” para avaliar o grau de lesão ao bem jurídico, necessário se faz acrescentar a análise da

${ }^{105}$ SANTOS, Lycurgo de Castro. Princípio da intervenção mínima do direito penal e crimies de menor potencial ofensivo - Lei 9099/95. Revista Justiça e Democracia. São Paulo: RT, n. 1, p. 204-205.

${ }^{106}$ SILVA, Ivan. Princípio da insignificância. p. 155.

${ }^{107}$ MAÑAS, Carlos Vico. O princípio da insignificância como excludente de tipicidade no direito penal. São Paulo: Saraiva, 1994, p. 60. 
danosidade social que, Alice Bianchini complementa observando que um nível ínfimo de danosidade social “deslegitima a atuação estatal”108.

Acerca da análise do desvalor da ação e do resultado, vale as lições de Luiz Regis Prado, a saber:

(...) tanto o desvalor da ação como o desvalor do resultado integram o conceito de injusto penal. O desvalor da ação não deve ser entendido como o desvalor da intenção (tese dualista objetiva), mas abrange, também, elementos objetivos (v.g., modo de execução). O desvalor da ação (dolo/culpa) se refere à forma de praticar o delito (elementos objetivos/subjetivos), e o desvalor do resultado alude à lesão ou perigo de lesão ao bem jurídico protegido ${ }^{109}$.

\section{E Ivan Luiz da Silva complementa:}

O índice desvalor da ação refere-se ao grau de probabilidade da conduta para realizar o evento na concreta modalidade lesiva assumida pelo agente. $\mathrm{O}$ índice desvalor do resultado é inferido da importância do bem jurídico atacado e da gravidade do dano provocado. A insignificância concorrente desses índices qualifica o fato como irrelevante para o Direito Penal ${ }^{110}$.

Ocorre que, dizer de que a insignificância é aferida por meio de um juízo valorativo sob a conduta e o resultado está longe de tornar algo pacífico em relação à análise do princípio em tela, uma vez que esta valoração é algo extremamente subjetivo. Desta forma, como a jurisprudência avançou um pouco mais nos critérios acerca do princípio da insignificância, passaremos a esta análise.

\section{2}

\section{Critérios de aplicação segundo a jurisprudência}

A jurisprudência do Supremo Tribunal Federal, tentando tornar menos subjetiva a análise da infração bagatelar, procurou estabelecer quatro vetores para a aplicação do princípio da insignificância, a saber:

\footnotetext{
${ }^{108}$ BIANCHINI, Alice. Pressupostos materiais mínimos da tutela penal: uma abordagem a partir dos postulados constitucionais. Tese de doutorado. São Paulo: PUC, 2001, p. 141.

109 PRADO, Luiz Regis. Curso de direito penal brasileiro. Parte Geral. 2. Ed. São Paulo: RT, 2000, p. 221.

${ }^{110}$ SILVA, Ivan. Princípio da insignificância. p. 156.
} 


\begin{abstract}
PRINCÍPIO DA INSIGNIFICÂNCIA - IDENTIFICAÇÃO DOS VETORES CUJA PRESENÇA LEGITIMA O RECONHECIMENTO DESSE POSTULADO DE POLÍTICA CRIMINAL - CONSEQÜENTE DESCARACTERIZAÇÃO DA TIPICIDADE PENAL EM SEU ASPECTO MATERIAL - DELITO DE FURTO - CONDENAÇÃO IMPOSTA A JOVEM DESEMPREGADO, COM APENAS 19 ANOS DE IDADE - "RES FURTIVA" NO VALOR DE R\$ 25,00 (EQUIVALENTE A 9,61\% DO SALÁRIO MÍNIMO ATUALMENTE EM VIGOR) - DOUTRINA - CONSIDERAÇÕES EM TORNO DA JURISPRUDÊNCIA DO STF - PEDIDO DEFERIDO. O PRINCÍPIO DA INSIGNIFICÂNCIA QUALIFICA-SE COMO FATOR DE DESCARACTERIZAÇÃO MATERIAL DA TIPICIDADE PENAL - - O princípio da insignificância - que deve ser analisado em conexão com os postulados da fragmentariedade e da intervenção mínima do Estado em matéria penal - tem o sentido de excluir ou de afastar a própria tipicidade penal, examinada na perspectiva de seu caráter material. Doutrina. Tal postulado - que considera necessária, na aferição do relevo material da tipicidade penal, a presença de certos vetores, tais como (a) a mínima ofensividade da conduta do agente, (b) a nenhuma periculosidade social da ação, (c) o reduzidíssimo grau de reprovabilidade do comportamento e (d) a inexpressividade da lesão jurídica provocada - apoiou-se, em seu processo de formulação teórica, no reconhecimento de que o caráter subsidiário do sistema penal reclama e impõe, em função dos próprios objetivos por ele visados, a intervenção mínima do Poder Público. O POSTULADO DA INSIGNIFICÂNCIA E A FUNÇÃO DO DIREITO PENAL: "DE MINIMIS, NON CURAT PRAETOR". - O sistema jurídico há de considerar a relevantíssima circunstância de que a privação da liberdade e a restrição de direitos do indivíduo somente se justificam quando estritamente necessárias à própria proteção das pessoas, da sociedade e de outros bens jurídicos que lhes sejam essenciais, notadamente naqueles casos em que os valores penalmente tutelados se exponham a dano, efetivo ou potencial, impregnado de significativa lesividade. O direito penal não se deve ocupar de condutas que produzam resultado, cujo desvalor - por não importar em lesão significativa a bens jurídicos relevantes - não represente, por isso mesmo, prejuízo importante, seja ao titular do bem jurídico tutelado, seja à integridade da própria ordem social (grifo nosso) ${ }^{111}$.
\end{abstract}

Neste contexto, passaremos a analisar cada um dos vetores apontados pelo Supremo.

\title{
3.2.1
}

\section{Ausência de periculosidade social da ação}

A ação perpetrada pelo agente deve ser incapaz de causar dano potencial à sociedade. Com base neste critério, o STF já decidiu ser insignificante um porte

\footnotetext{
${ }^{111}$ STF - HC: 84412 SP , Relator: CELSO DE MELLO, Data de Julgamento: 19/10/2004, Segunda Turma, Data de Publicação: DJ 19-11-2004 PP-00037 EMENT VOL-02173-02 PP-00229 RT v. 94, n. 834, 2005, p. 477-481 RTJ VOL-00192-03 PP-00963.
} 
de quantidade de drogas ínfima para uso pessoal, ainda que em âmbito militar, senão vejamos:

HABEAS CORPUS. CONSTITUCIONAL. PENAL E PROCESSUAL PENAL MILITAR. PACIENTE DENUNCIADO PELA INFRAÇÃO DO ART. 290 DO CÓDIGO PENAL MILITAR. ALEGAÇÃO DE INCIDÊNCIA DO PRINCÍPIO DA INSIGNIFICÂNCIA. PRECEDENTES DO SUPREMO TRIBUNAL FAVORÁVEIS À TESE DA IMPETRAÇÃO: NÃO APLICAÇÃO À ESPÉCIE VERTENTE. PRINCÍPIO DA ESPECIALIDADE. HABEAS CORPUS INDEFERIDO. 1. A existência de decisão neste Supremo Tribunal no sentido pretendido pela Impetrante, inclusive admitindo a incidência do princípio da insignificância à justiça castrense, "a despeito do princípio da especialidade e em consideração ao princípio maior da dignidade humana" (Habeas Corpus n. 92.961, Rel. Ministro Eros Grau, DJ 21.2.2008), não é bastante a demonstrar como legítima sua pretensão. 2. Nas circunstâncias do caso, o fato não é penalmente irrelevante, pois a droga apreendida, além de ter sido encomendada por outra pessoa, seria suficiente para o consumo de duas pessoas, o que configuraria, minimamente, a periculosidade social da ação do Paciente. 3. A jurisprudência predominante do Supremo Tribunal Federal é no sentido de reverenciar a especialidade da legislação penal militar e da justiça castrense, sem a submissão à legislação penal comum do crime militar devidamente caracterizado. 4. Habeas corpus indeferido ${ }^{112}$.

\section{2 .2}

\section{Reduzido grau de reprovabilidade do comportamento}

Em relação ao critério em tela o STF já deixou de aplicar o princípio da insignificância em relação ao furto de um celular praticado por um militar, tendo em vista o alto grau de reprovabilidade de um militar ao praticar tal ato em serviço, a saber:

EMENTA: HABEAS CORPUS. PENAL MILITAR. PACIENTE CONDENADO PELO CRIME DE FURTO. PRINCÍPIO DA INSIGNIFICÂNCIA. INAPLICABILIDADE. RAZOÁVEL GRAU DE REPROVABILIDADE DA CONDUTA. BEM QUE NÃO PODE SER CONSIDERADO DE VALOR ÍNFIMO. ORDEM DENEGADA. I - A aplicação do princípio da insignificância de modo a tornar a conduta atípica exige, além da pequena expressão econômica do bem que fora objeto de subtração, um reduzido grau de reprovabilidade da conduta do agente. II - É relevante e reprovável a conduta de um militar que, em serviço, furta bem de um colega de farda, demonstrando desrespeito às leis e às instituições de seu País. III - No caso em

112 STF - HC: 94649 RJ , Relator: Min. CÁRMEN LÚCIA, Data de Julgamento: 12/08/2008, Primeira Turma, Data de Publicação: DJe-192 DIVULG 09-10-2008 PUBLIC 10-10-2008 EMENT VOL-02336-02 PP-00256. 
espécie, o bem subtraído - um aparelho celular avaliado em R\$ 699,00 - não pode ser considerado de ínfimo valor, mormente quando considerados os vencimentos percebidos pelo ofendido - soldado do Exército. IV - Ordem denegada. ${ }^{113}$

\subsection{3}

\section{A mínima ofensividade da conduta}

A ofensividade da conduta perpetrada pelo agente deve ser mínima considerando todos os aspectos dos bens jurídicos protegidos pelo direito penal. Neste ponto, vale citar a decisão em que o STF deixou de aplicar o princípio da insignificância de um militar que praticou peculato-furto de munições, tendo em vista que a conduta, ainda que não relevante ao patrimônio, atentaria contra a administração militar.

EMENTA : HABEAS CORPUS. CRIME MILITAR. PECULATO-FURTO. MUNIÇÕES DE ARMAMENTO DE USO RESTRITO DAS FORÇAS ARMADAS. INAPLICABILIDADE DO POSTULADO DA INSIGNIFICÂNCIA. HABEAS CORPUS DENEGADO. 1. Para que se dê a incidência da norma penal, não basta a simples adequação formal do fato empírico ao tipo legal. É preciso que a conduta delituosa se contraponha, em substância, ao tipo penal em causa, sob pena de se provocar a desnecessária mobilização de u’a máquina custosa, delicada e ao mesmo tempo complexa como é o aparato de poder em que o Judiciário consiste. Poder que não é de ser acionado para, afinal, não ter o que substancialmente tutelar. 2. Numa visão humanitária do Direito Penal, então, é de se prestigiar o princípio da insignificância, que, se bem aplicado, não chega a estimular a idéia de impunidade. Ao tempo que se verificam patentes a necessidade e a utilidade desse princípio da tolerância, é imprescindível que a sua aplicação se dê de maneira criteriosa, sempre tendo em conta a realidade brasileira, para evitar que a atuação estatal vá além dos limites do razoável na proteção do interesse público. 3. No caso, o paciente, sargento de munição e tiro de unidade militar, subtraiu munições de armamentos de uso restrito das Forças Armadas. Donde a impossibilidade de se acatar a tese da irrelevância jurídico-penal da conduta, não obstante a pouca expressividade financeira da avaliação dos bens subtraídos pelo militar. A lesividade da conduta protagonizada pelo paciente não é de ser aferida pelo valor econômico da coisa furtada; até mesmo em consideração à própria qualidade da relação jurídica entre o militar acusado e a instituição castrense da qual fazia parte por ocasião da atividade delituosa. Logo, ainda que o valor das munições apreendidas seja de pequena monta, obsta a pretensão defensiva o fato de que o delito em causa não se constitui, apenas, em lesão de cunho patrimonial. É modalidade delitiva que também atenta contra a "Administração Militar"

113 STF - HC: 107240 RJ , Relator: Min. RICARDO LEWANDOWSKI, Data de Julgamento: 05/04/2011, Primeira Turma, Data de Publicação: DJe-075 DIVULG 19-04-2011 PUBLIC 25-042011. 
(Capítulo II do Título VII do Código Penal Militar). Precedente: HC 104.787, da minha relatoria. 4. Ordem denegada. ${ }^{114}$

\subsection{4}

\section{A inexpressividade da lesão jurídica provocada}

Este vetor se refere ao desvalor do resultado, ou seja, o grau de lesão ou perigo de lesão ao bem jurídico tutelado deve ser ínfimo, incapaz de justificar a intervenção estatal penal. Neste ponto, o STF já deixou de aplicar o princípio da insignificância ao delito de moeda falsa, tendo em vista de que, mesmo que o valor das notas sejam pequenos, o bem jurídico tutelado pelo crime (fé pública), foi periclitado de forma significativa.

PENAL. HABEAS CORPUS. MOEDA FALSA. ART. 289, § $1^{\circ}$, DO CÓDIGO PENAL. DEZ NOTAS DE PEQUENO VALOR. PRINCÍPIO DA INSIGNIFICÂNCIA. INAPLICABILIDADE. DESVALOR DA AÇÃO E DO RESULTADO. IMPOSSIBILIDADE DE QUANTIFICAÇÃO ECONÔMICA DA FÉ PÚBLICA EFETIVAMENTE LESIONADA. DESNECESSIDADE DE DANO EFETIVO AO BEM SUPRA-INDIVIDUAL. ORDEM DENEGADA. I A aplicação do princípio da insignificância de modo a tornar a conduta atípica depende de que esta seja a tal ponto despicienda que não seja razoável a imposição da sanção. II - Mostra-se, todavia, cabível, na espécie, a aplicação do disposto no art. 289, $\S 1^{\circ}$, do Código Penal, pois a fé pública a que o Título X da Parte Especial do CP se refere foi vulnerada. III - Em relação à credibilidade da moeda e do sistema financeiro, o tipo exige apenas que estes bens sejam colocados em risco, para a imposição da reprimenda. IV - Os limites da culpabilidade e a proporcionalidade na aplicação da pena foram observados pelo julgador monocrático, que substituiu a privação da liberdade pela restrição de direitos, em grau mínimo. V - Ordem denegada ${ }^{115}$.

Pelo exposto, vimos que os critérios estabelecidos pelo STF auxiliam na aferição da aplicação do princípio da insignificância, mas não pacificam as discussões, tendo em vista a carga valorativa do princípio em tela impede a fixação de critérios de forma taxativa, de modo que é imprescindível que o interprete avalie todas as circunstâncias do caso concreto.

\footnotetext{
${ }^{114}$ STF - HC: 104820 SP , Relator: Min. AYRES BRITTO, Data de Julgamento: 07/12/2010, Segunda Turma, Data de Publicação: DJe-109 DIVULG 07-06-2011 PUBLIC 08-06-2011 EMENT VOL-02539-01 PP-00104.

115 STF - HC: 93251 DF , Relator: Min. RICARDO LEWANDOWSKI, Data de Julgamento: 05/08/2008, Primeira Turma, Data de Publicação: DJe-157 DIVULG 21-08-2008 PUBLIC 22-082008 EMENT VOL-02329-03 PP-00497 RT v. 97, n. 877, 2008, p. 515-517.
} 
No âmbito do Supremo Tribunal Federal existe um julgado que tentou estabelecer diretrizes mais detalhadas acerca da aplicação do princípio da insignificância, o qual merece a análise, a saber:

Ementa: HABEAS CORPUS. CRIME DE TENTATIVA DE FURTO AGRAVADO. PACIENTE REINCIDENTE ESPECÍFICO. DIRETIVAS DE APLICAÇÃO DO PRINCÍPIO DA INSIGNIFICÂNCIA. JUSTIÇA MATERIAL. PONDERABILIDADE NO JUÍZO DE ADEQUAÇÃO TÍPICA DE CONDUTAS FORMALMENTE CRIMINOSAS. SIGNIFICÂNCIA PENAL. CONCEITO CONSTITUCIONAL. ORDEM DENEGADA. 1. A norma legal que descreve o delito e comina a respectiva pena atua por modo necessariamente binário, no sentido de que, se, por um lado, consubstancia o poder estatal de interferência na liberdade individual, também se traduz na garantia de que os eventuais arroubos legislativos de irrazoabilidade e desproporcionalidade se expõem a controle jurisdicional. Donde a política criminal-legislativa do Estado sempre comportar mediação judicial, inclusive quanto ao chamado "crime de bagatela" ou postulado da insignificância penal” da conduta desse ou daquele agente. Com o que o tema da significância penal confirma que o devido processo legal” a que se reporta a Constituição Federal no inciso LIII do art. $5^{\circ}$ é de ser interpretado como um devido processo legal substantivo ou material. Não meramente formal. 2. A insignificância penal expressa um necessário juízo de razoabilidade e proporcionalidade de condutas que, embora formalmente encaixadas no molde legal-punitivo, substancialmente escapam desse encaixe. E escapam desse molde simplesmente formal, como exigência mesma da própria justiça material enquanto valor ou bem coletivo que a nossa Constituição Federal prestigia desde o seu principiológico preâmbulo. Justiça como valor, a se concretizar mediante uma certa dosagem de razoabilidade e proporcionalidade na concretização dos valores da liberdade, igualdade, segurança, bem-estar, desenvolvimento, etc. Com o que ela, justiça, somente se realiza na medida em que os outros valores positivos se realizem por um modo peculiarmente razoável e proporcional. 3. A justiça não tem como se incorporar, sozinha, à concreta situação das protagonizações humanas, exatamente por ser ela a própria resultante de uma certa cota de razoabilidade e proporcionalidade na historicização de valores positivos (os mencionados princípios da liberdade, da igualdade, da segurança, do bem-estar, do desenvolvimento, etc.). Daí que falar do valor da justiça é falar dos outros valores que dela venham a se impregnar por se dotarem de um certo quantum de ponderabilidade, se por este último termo (ponderabilidade) englobarmos a razoabilidade e a proporcionalidade no seu processo de concreta incidência. Assim como falar dos outros valores é reconhecê-los como justos na medida em que permeados desse efetivo quantum de ponderabilidade (mescla de razoabilidade e proporcionalidade, torna-se a dizer). Tudo enlaçado por um modo sinérgico, no sentido de que o juízo de ponderabilidade implica o mais harmonioso emprego do pensamento e do sentimento do julgador na avaliação da conduta do agente em face do seu subjetivado histórico de vida e da objetividade da sua concreta conduta alegadamente delitiva. 4. É possível extrair do ordenamento jurídico brasileiro a premissa de que toda conduta penalmente típica só é penalmente típica porque significante, de alguma forma, para a sociedade e para a própria vítima. Em tema de política criminal, a Constituição Federal pressupõe lesão significante a interesses e valores (os chamados "bens jurídicos") por ela avaliados como dignos de proteção normativa. 5. Ao prever, por exemplo, a categoria de infrações de menor potencial ofensivo (inciso I do art. 98), a 
Constituição Federal logicamente nega a significância penal de tudo que ficar aquém desse potencial, de logo rotulado de "menor"; ou seja, quando a Constituição Federal concebe a categoria das infrações de menor potencial ofensivo, parece mesmo que o faz na perspectiva de uma conduta atenuadamente danosa para a vítima e a sociedade, é certo, mas ainda assim em grau suficiente de lesividade para justificar uma reação estatal punitiva. Pelo que estabelece um vínculo operacional direto entre o efetivo dano ao bem jurídico tutelado, por menor que seja, e a necessidade de uma resposta punitiva do Estado. 6. A contrario sensu, o dano que subjaz à categoria da insignificância penal não caracteriza, materialmente, sequer lesão de pequena monta; ou seja, trata-se de ofensividade factualmente nula, porquanto abaixo até mesmo da concepção constitucional de dano menor. Donde sua categorização como penalmente atípica. 7. É possível listar diretrizes de aplicação do princípio da insignificância, a saber: a) da perspectiva do agente, a conduta, além de revelar uma extrema carência material, ocorre numa concreta ambiência de vulnerabilidade social do suposto autor do fato; b) do ângulo da vítima, o exame da relevância ou irrelevância penal deve atentar para o seu peculiarmente reduzido sentimento de perda por efeito da conduta do agente, a ponto de não experimentar revoltante sensação de impunidade ante a não-incidência da norma penal que, a princípio, lhe favorecia; c) quanto aos meios e modos de realização da conduta, não se pode reconhecer como irrelevante a ação que se manifesta mediante o emprego de violência ou ameaça à integridade física, ou moral, tanto da vítima quanto de terceiros. Reversamente, sinaliza infração de bagatela ou penalmente insignificante aquela que, além de não se fazer acompanhar do modus procedendi que estamos a denunciar como intolerável, revela um atabalhoamento ou amadorismo tal na sua execução que antecipa a sua própria frustração; isto é, já antecipa a sua marcante propensão para a forma não mais que tentada de infração penal, porque, no fundo, ditadas por um impulso tão episódico quanto revelador de extrema carência econômica; d) desnecessidade do poder punitivo do Estado, traduzida nas situações em que a imposição de uma pena se auto-evidencie como tão despropositada que até mesmo a pena mínima de privação liberdade, ou sua conversão em restritiva de direitos, já significa um desbordamento de qualquer idéia de proporcionalidade; e) finalmente, o objeto material dos delitos patrimoniais há de exibir algum conteúdo econômico, seja para efetivamente desfalcar ou reduzir o patrimônio da vítima, seja para ampliar o acervo de bens do agente. 8. No caso, o paciente é reincidente específico quanto ao crime de furto. Pelo que a tentativa de furto agravado de bens avaliados em R\$ 180,00 (cento e oitenta reais), mediante a invasão de uma empresa, não se amolda à ponderabilidade de todas as diretivas acima listadas. 9. Habeas corpus denegado (grifo nosso) $^{116}$.

Ressalte-se que a decisão supracitada, além de analisar o fato, analisa a perspectiva do autor, da vítima e do interesse do Estado na persecução penal. Em relação à análise do autor, ou seja, se caberia na insignificância uma análise subjetiva, a jurisprudência e doutrina é bastante controvertida.

No sentido de ser considerado apenas critérios objetivos,

${ }^{116}$ STF - HC: 107082 RS , Relator: Min. AYRES BRITTO, Data de Julgamento: 27/03/2012, Segunda Turma, Data de Publicação: DJe-081 DIVULG 25-04-2012 PUBLIC 26-04-2012. 
(...) Asseverou-se que para a incidência do princípio da insignificância somente devem ser considerados aspectos objetivos, referentes à infração praticada, tais como: mínima ofensividade da conduta do agente; ausência de periculosidade social da ação; reduzido grau de reprovabilidade do comportamento; inexpressividade da lesão jurídica causada. Destarte, concluiu-se que para a caracterização de ato jurídico como insignificante são incabíveis considerações de ordem subjetiva, consoante reputado pelo acórdão recorrido, que afastara a incidência do princípio da bagatela com base na existência de vários registros contra o agravante pelo mesmo delito, ainda que não houvesse notícia de condenação transitada em julgado. Por fim, afirmou-se que, em se tratando de ato insignificante, este torna-se atípico, a impor o trancamento da ação penal por falta de justa causa. Precedentes citados: HC 84412/SP (DJU de 19.11.2004); HC 77003/PE (RTJ 178/310) ${ }^{117}$.

Ocorre que, o próprio Supremo Tribunal Federal, em decisão posterior, passou a analisar o autor do crime, com a preocupação da consolidação da aplicação objetiva do princípio da insignificância acarretar em um estimulo à prática de condutas ínfimas formalmente típicas, a saber:

1. A tipicidade penal não pode ser percebida como o exercício de mera adequação do fato concreto à norma abstrata. Além da correspondência formal, a configuração da tipicidade demandaria uma análise materialmente valorativa das circunstâncias do caso concreto, para verificar a ocorrência de alguma lesão grave, contundente e penalmente relevante do bem jurídico tutelado.

2. Reincidência do Recorrente assentada nas instâncias antecedentes. O criminoso contumaz, mesmo que pratique crimes de pequena monta, não pode ser tratado pelo sistema penal como se tivesse praticado condutas irrelevantes, pois crimes considerados ínfimos, quando analisados isoladamente, mas relevantes quando em conjunto, seriam transformados pelo infrator em verdadeiro meio de vida. 3. O princípio da insignificância não pode ser acolhido para resguardar e legitimar constantes condutas desvirtuadas, mas para impedir que desvios de conduta ínfimos, isolados, sejam sancionados pelo direito penal, fazendo-se justiça no caso concreto. Comportamentos contrários à lei penal, mesmo que insignificantes, quando constantes, devido à sua reprovabilidade, perdem a característica da bagatela e devem se submeter ao direito penal ${ }^{118}$.

Em que pese a crítica doutrinária de que a consideração de critérios subjetivos no princípio da insignificância revelaria expressão do direito penal do inimigo, próprio de regimes totalitários, ao nosso ver não merece prosperar, uma vez que, defendemos ter o princípio em tela uma função interpretativa, mas a elaboração de critérios para sua aplicação ficou a cargo do aplicador do direito. Desta forma, nada mais racional do que se considerar as características do sujeito realizador da conduta, uma vez que o direito penal, além de ter uma função de

\footnotetext{
${ }^{117}$ STF AI 559.904 QO/RS, rel. Min. Sepulveda Pertence, 07.06.2005 (Informativo STF 391). ${ }^{118}$ http://www.migalhas.com.br/dePeso/16\%2cMI194625\%2c61044STF+A+criminalidade+de+ba gatela+e+a+reincid\%C3\%AAncia. Acesso em 10/03/2014.
} 
defesa do cidadão em face do Estado, também tem a função de defesa dos bens jurídicos mais valiosos, possibilitando um bom convívio social, o que seria certamente abalado pela internalização, por exemplo, de que subtrações de valor ínfimo de patrimônio alheio seriam irrelevantes para o direito penal.

Pelo exposto, somaríamos alguns vetores aos quatro já mencionados pelo STF, a saber:

Em relação à conduta:

a) Ausência de periculosidade social da ação

b) Reduzido grau de reprovabilidade do comportamento

c) Mínima ofensividade da conduta

d) Circunstâncias do fato favoráveis

Em relação ao resultado:

e) Inexpressividade da lesão ou perigo de lesão provocada Em relação à vítima:

f) Colaboração ou não para o fato

g) Sensação de perda provocada

Em relação ao autor:

h) Antecedentes criminais

i) Circunstâncias pessoais para a prática do crime (econômicas e/ou psicológicas)

Vislumbramos que tais vetores auxiliam numa interpretação da norma penal de acordo com a dupla finalidade do Direito Penal: tutela dos bens jurídicos mais importantes e de estabelecer garantias dos cidadãos em face do Estado.

É importante que se diga que, embora acreditamos que tais vetores contribuiriam para uma aplicação mais justa do princípio da insignificância, não podemos negar que não há como esgotar os elementos de análise do princípio uma vez que, só diante do caso concreto é possível mensurar e valorar a ação e o resultado perpetrado. 


\section{3 \\ Consequencia da aplicação dos princípios da insignificância e da irrelevância penal do fato nas diversas modalidades de crimes}

Neste tópico iremos analisar a aplicação do princípio da insignificância e da irrelevância penal do fato nas diversas modalidades de crimes, razão pela qual iremos fazer uma subdivisão para melhor compreensão.

\subsection{1}

\section{Insignificância e crimes contra o patrimônio sem violência e grave ameaça}

Em relação ao furto e demais delitos patrimoniais sem cometimento mediante violência ou grave ameaça a jurisprudência é quase pacífica na aplicação do princípio da insignificância. A título de exemplo, temos o HC 109.363/MG em que o Supremo Tribunal Federal entendeu que o furto, ainda que praticado com a qualificadora de rompimento de obstáculo, de um carrinho de mão, seria materialmente atípico com fulcro no princípio em estudo.

Insta salientar que a jurisprudência vem buscando diferenciar o furto privilegiado (pequeno valor) de uma subtração de valor ínfimo (a qual teria a aplicação do princípio da insignificância) ${ }^{119}$. Ocorre que, somente o valor do objeto subtraído não é, por si só, parâmetro para a aplicação da insignificância, pois se faz sempre necessário a valoração do caso concreto com todas as suas circunstâncias, pois uma subtração de uma garrafa de água na cidade, pode ser considerada insignificante, mas num deserto, provavelmente não.

Cumpre salientar que, em relação aos criminosos contumazes a aplicação já gera controversa, razão pela qual iremos abordar o tema em tópico próprio.

${ }^{119}$ GOMES, Luiz Flávio. Princípio da insignificância. pp.157-158. 


\subsection{2 \\ Insignificância e crimes contra o patrimônio com violência ou grave ameaça}

No âmbito jurisprudencial, tem prevalecido a impossibilidade de aplicação do princípio da insignificância em razão do emprego de violência ou grave ameaça na subtração, entendendo-se que o fato não pode ser taxado como um comportamento de grau reduzido de reprovabilidade ${ }^{120}$, levando em conta, portanto, o $3^{\circ}$ critério definido pelo Supremo Tribunal Federal.

Cabo ressaltar que, em relação ao roubo, temos uma jurisprudência marcante do Tribunal de Justiça do Mato Grosso do Sul, em que foi aplicado o princípio da irrelevância penal do fato. Isso porque, a conduta nasce relevante para o direito penal, por isso, não é possível a aplicação da insignificância, mas a pena verifica-se desnecessária por vários fatores como: bons antecedentes, reparação dos danos, reconhecimento da culpa, prisão cautelar, etc ${ }^{121}$. A título de exemplo, podemos citar um usuário de crack primário de bons antecedentes que, na fissura de satisfazer seu vício subtrai, mediante grave ameaça R \$10,00 de uma pessoa, no entanto, é preso em flagrante e restitui o valor à vítima, reconhecendo sua culpa. No caso em tela, embora a conduta e o resultado tenham sido relevantes, a pena se mostra desnecessária para o caso, por isso no tópico anterior salientamos a diferenciação entre o princípio da insignificância e o da irrelevância penal do fato, sendo que neste caso seria aplicado este.

\subsection{3}

\section{Insignificância e crimes contra a Administração pública}

No âmbito jurisprudencial, o Superior Tribunal de Justiça e Supremo Tribunal Federal tem divergido acerca da aplicação ou não do princípio em tela no âmbito dos crimes contra a Administração Pública ${ }^{122}$.

\footnotetext{
${ }^{120}$ HC 97.190, Rel. Min. Dias Toffoli. Dje-190, 07-10-2010.

${ }^{121}$ GOMES, Luiz Flávio. Princípio da insignificância. pp.28-29.

122 GUSTAVO, Junqueira/VANZOLINI, Patrícia. Manual de direito penal. São Paulo: Saraiva, 2013, p. 50.
} 
No Superior Tribunal de Justiça, tem prevalecido a impossibilidade de aplicação, tendo em vista que, além do patrimônio, atinge-se a moralidade administrativa, garantida constitucionalmente ${ }^{123}$, desta forma, também levam em consideração o não preenchimento do $3^{\circ}$ vetor, ou seja, mínima ofensividade da conduta em relação a todos os bens jurídicos tutelados.

Já no Supremo Tribunal Federal, encontramos julgados nos dois sentidos, entretanto, hodiernamente, tem prevalecido a possibilidade de aplicação do princípio. Como exemplo, temos o HC 107.370, em que fora considerado insignificante a subtração de objetos da Administração totalizados em R \$130,00.

Não vislumbramos qualquer problema na aplicação do princípio em tela nos crimes contra a Administração, uma vez que a justificativa da não aplicação em face da moralidade administrativa ser garantia constitucional, não nos parece um obstáculo, tendo em vista que demonstramos que o princípio da insignificância também tem o status constitucional, ainda que decorrente apenas implicitamente do texto constitucional. Cabe ressaltar que o princípio em tela vislumbramos ter um grau de importância maior na ponderação da colisão constitucional em tela, uma vez que é uma garantia do cidadão em face do Estado.

\subsection{4}

\section{Insignificância e porte de droga para uso pessoal}

No âmbito jurisprudencial e doutrinário o tema tem sido bastante controvertido a insignificância em relação ao delito de uso de drogas. Existem basicamente dois caminhos jurídicos que defendem a descriminalização de tal crime: princípio da ofensividade, tendo que em vista que o uso não afeta bens jurídicos de terceiros (seguido recentemente pela Suprema corte argentina) e o do princípio da insignificância, o qual defende que a posse de quantidade ínfima para uso pessoal seria incapaz de causar relevante perigo de lesão ao bem jurídico tutelado ${ }^{124}$.

\footnotetext{
${ }^{123}$ HC 167.515/SP, Rel. Min. Laurita Vaz, 5 a Turma, julgado em 16-11-2010, DJe 6-12-2010.

${ }^{124}$ GOMES, Luiz Flávio. Princípio da insignificância. p.137.
} 
Cabe ressaltar que o STF aplicou a insignificância, inclusive, no âmbito militar, no HC 91.074-2-SP, em que o militar tinha em posse 4,7 gramas de maconha para uso pessoal.

Entretanto, ainda existem julgados negando a aplicação do princípio no delito em tela. No HC 102.940, em que o relator foi o Ministro Ricardo Lewandowski, consignou-se a inaplicabilidade em face da periculosidade social da ação, alegando que trata-se de um crime de perigo abstrato.

Não vislumbramos qualquer obstáculo para a aplicação do princípio da insignificância no crime em comento, uma vez que, como vimos, o princípio serve como guia para o intérprete da lei no sentido de excluir do âmbito de incidência do direito penal, condutas e/ou resultados irrelevantes. Desta forma, embora seja uma conduta socialmente relevante se, as circunstâncias do caso concreto demonstrarem que a ínfima quantidade de droga para uso próprio é incapaz de causar relevante perigo de lesão ao bem jurídico tutelado que no caso é a incolumidade pública, insignificante será o fato para a tutela do direito penal.

Em relação ao delito de tráfico, a jurisprudência não vem admitindo a aplicação do princípio da insignificância, tendo em vista o grau de ofensividade da conduta para bens jurídicos de terceiros. Entretanto, vislumbramos a possibilidade de aplicação do princípio da irrelevância pela do fato num caso, por exemplo, de um estudante que num carnaval pega seu "lança perfume" comprado para uso pessoal e vende para atender uma necessidade de dinheiro. Sendo primário, de bons antecedentes, ficando submetido a certo tempo de prisão cautelar, pode ser que a prisão para o caso em tela seja desnecessária, razão pela qual poderia se invocar o princípio da irrelevância penal do fato.

\subsection{5}

\section{Insignificância no descaminho e crimes contra a ordem tributária}

O Supremo Tribunal Federal tem considerado insignificante o descaminho sempre que o valor do tributo não exceder a R $\$ 10.000,00$, com base no art. 20 da Lei 10.522/02, que determina o arquivamento de débitos de valores iguais ou 
inferiores ao referido montante. Ressalte-se que o valor atual que dispensa o ingresso de cobrança fiscal em juízo é de $\mathrm{R} \$ 20.000,00$, conforme art. $1^{\circ}$, II da portaria n. 75/2012 do Ministério da Fazenda ${ }^{125}$.

Insta salientar que o STF não vem admitindo a aplicação do princípio em tela no delito de contrabando, muito embora, esteja no mesmo tipo penal do art. 334 do Código Penal (HC 110964 SC).

\title{
3.3.6
}

\section{Insignificância e ato infracional}

O Supremo Tribunal Federal tem entendido ser plenamente aplicável o princípio da insignificância aos atos infracionais, senão vejamos:

\begin{abstract}
A Turma deferiu habeas corpus em que se pretendia a extinção de procedimento judicial de aplicação de medida sócio-educativa a menor inimputável, instaurado em razão da prática de ato infracional equiparado ao crime de furto. Salientou-se, de início, que, embora a impetração se insurgisse contra decisão monocrática proferida por Ministro do STJ que indeferira o pleito liminar aduzido perante aquela Corte, fazia-se necessária a superação da Súmula 691/STF, ponderadas as particularidades do writ. Em seguida, considerou-se incidir, no caso, o princípio da insignificância, uma vez que a conduta imputada ao paciente, de que lhe resultara a imposição de medida sócio-educativa de internação, caracterizaria ato infracional equivalente ao delito de furto de objeto avaliado em quinze reais. Esse elemento, aliado às demais circunstâncias em torno do ato, afastaria a tipicidade da conduta, o que evidenciaria a ausência de justa causa do procedimento instaurado contra o paciente, à luz do referido princípio $^{126}$.
\end{abstract}

Assim, embora o menor seja inimputável, os reflexos da prática do ato infracional, são semelhantes aos reflexos penais, de forma que seria desproporcional punir o menor infrator por um ato que o maior não será responsabilizado penalmente em face do princípio da insignificância.

\footnotetext{
${ }^{125}$ ESTEFAM, André/GONÇALVES, Victor Eduardo Rios. Direito penal esquematizado: parte geral, p. 127.

${ }^{126}$ HC 102655/RS, rel. Min. Celso de Mello, 22.6.2010. Informativo 592 STF.
} 


\subsection{7}

\section{Insignificância e crimes ambientais}

Tanto o Supremo Tribunal Federal, quanto o Superior Tribunal de Justiça tem aplicado o princípio em tela aos crimes ambientais, a saber:

CRIME - INSIGNIFICÂNCIA - MEIO AMBIENTE. Surgindo a insignificância do ato em razão do bem protegido, impõe-se a absolvição do acusado ${ }^{127}$

PENAL. HABEAS CORPUS . CRIME CONTRA O MEIO AMBIENTE (ART. 40 DA LEI No 9.605/95). CORTE DE UMA ÁRVORE. COMPENSAÇAO DO EVENTUAL DANO AMBIENTAL. CONDUTA QUE NAO PRESSUPÔS MÍNIMA OFENSIVIDADE AO BEM JURÍDICO TUTELADO. PRINCÍPIO DA INSIGNIFICÂNCIA. ATIPICIDADE MATERIAL DA CONDUTA. ORDEM CONCEDIDA.

1. É de se reconhecer a atipicidade material da conduta de suprimir um exemplar arbóreo, tendo em vista a completa ausência de ofensividade ao bem jurídico tutelado pela norma penal.

2. Ordem concedida, acolhido o parecer ministerial, para reconhecer a atipicidade material da conduta e trancar a Ação Penal $n^{\circ}$ 002.05.038755-5, Controle ${ }^{0}$ 203/07, da Vigésima Quarta Vara Criminal da comarca de São Paulo ${ }^{128}$.

No caso em tela é importante ressaltar que, independente da natureza do crime, se a conduta perpetrada é incapaz de lesar significativamente o bem jurídico tutelado, não há que se falar em intervenção penal.

\subsection{8}

\section{Insignificância e posse ilegal de arma de fogo}

Luiz Flávio Gomes defende a aplicação do referido princípio aos delitos de posse ilegal de arma de fogo, senão vejamos:

sustentamos a possibilidade de incidência do princípio da insignificância em relação à posse ilegal de arma de fogo em residência, desde que a arma esteja devidamente guardada, caso em que o nível de perigo é ínfimo. Na atualidade, esse princípio pode ser aplicado em relação ao art. 12 do Estatuto do Desarmamento (Lei 10826/03) assim como ao verbo possuir (do art. 16). Ambos, centrados no verbo possuir, punem a conduta de ter sob guarda arma de fogo em

${ }^{127}$ STF - AP: 439 SP , Relator: MARCO AURÉLIO, Data de Julgamento: 12/06/2008, Tribunal Pleno, Data de Publicação: DJe-030 DIVULG 12-02-2009 PUBLIC 13-02-2009 EMENT VOL02348-01 PP-00037

${ }^{128}$ STJ , Relator: Ministra MARIA THEREZA DE ASSIS MOURA, Data de Julgamento: 31/05/2011, T6 - SEXTA TURMA. 
residência ou empresa (no que diz respeito ao seu titular). Esse, aliás, é o sentido do verbo possuir, que não se confunde com o verbo portar ${ }^{129}$.

Em que pese a posição do renomado jurista supracitada, é importante que façamos algumas observações. Primeiramente, é inconcebível que se defenda que toda arma que esteja devidamente guardada não é capaz de oferecer relevante perigo de lesão à incolumidade pública, pois, caso contrário, sequer teria sentido a referida lei a qual pune severamente tal conduta justamente por sua periculosidade potencial. No entanto, não estamos aqui negando a aplicação do princípio em tela, mas exigindo para a devida aplicação que a conduta, no caso concreto, realmente seja ínfima, como, por exemplo, daquele que possui armas de fogo como peças de decoração, sem munição, ou aquele que possui apenas uma única munição. Neste sentido, STJ:

\section{PORTE ILEGAL DE MUNIÇÃO. AUSÊNCIA DE ARMA DE FOGO.}

A Turma, por maioria, absolveu o paciente do crime de porte ilegal de munição; ele fora preso com um único projétil, sem ter havido apreensão da arma de fogo. O Min. Relator entendeu que se trata de crime de perigo abstrato, em que não importa se a munição foi apreendida com a arma ou isoladamente para caracterizar o delito. Contudo, no caso, verificou que não houve lesão ao bem jurídico tutelado na norma penal, que visa resguardar a segurança pública, pois a munição foi utilizada para suposta ameaça, e não é esse tipo de perigo, restrito a uma única pessoa, que o tipo penal visa evitar. E, por se tratar de apenas um projétil, entendeu pela ofensividade mínima da conduta, portanto por sua atipicidade. A Min. Maria Thereza de Assis Moura e o Min. Og Fernandes também reconheceram a atipicidade da conduta, mas absolveram o paciente sob outro fundamento: o crime de porte de munição é de perigo concreto, ou seja, a munição sem arma não apresenta potencialidade lesiva. Precedente citado do STF: HC 96.532-RS, DJe 26/11/2009 ${ }^{130}$.

Ademais, cumpre esclarecer que também entendemos incabível a aplicação do princípio da insignificância para algumas condutas do art. 16 do Estatuto do desarmamento, por exemplo, a de possuir arma com numeração suprimida (art. 16, parágrafo único, inciso IV), tendo em vista que tal conduta também afeta o poder de fiscalização do estado em face dos armamentos.

\footnotetext{
${ }^{129}$ GOMES, Luiz Flávio. Princípio da insignificância. p.131.

${ }^{130}$ HC 194.468-MS, Rel. Min. Sebastião Reis Júnior, julgado em 17/4/2012.
} 


\subsection{9}

\section{Insignificância, réu reincidente e reiteração de conduta}

Um dos temas mais controvertidos no âmbito jurisprudencial é a aplicação do princípio da insignificância em relação ao réu reincidente na prática criminosa. Neste contexto, Luiz Flávio Gomes estabelece uma distinção importante sobre o tema, a qual classifica como: multirreincidência ou reiteração cumulativa, multirreincidência ou reiteração não cumulativa e fato único insignificante cometido por réu reincidente ${ }^{131}$.

Conforme a classificação acima, passaremos a analisar o tema em tela, sob a ótica exposta, senão vejamos:

\subsubsection{1}

\section{Multirreincidência ou reiteração cumulativa:}

Este fator seria a soma de várias condutas ínfimas praticadas por uma só pessoa, que poderia transformar a lesão ao bem jurídico em relevante. Como exemplo, podemos citar um hacker ou gerente de banco que desvia $\mathrm{R} \$ 1,00$ de cada conta corrente, perfazendo o montante de $\mathrm{R} \$ 1.000 .000,00^{132}$.

Neste ponto, cabe ressaltar que devemos considerar as condutas como um fato único, de forma que a soma dos atos faz com que a conduta ganhe relevância ao direito penal, não havendo que se falar em aplicação do princípio da insignificância ${ }^{133}$.

\subsubsection{2}

\section{Multirreincidência ou reiteração não cumulativa:}

Esta reiteração não cumulativa está ligada a fatos insignificantes praticados de forma desconexa, em tempo e locais diversos, sem a intensão de

\footnotetext{
${ }^{131}$ GOMES, Luiz Flávio. Princípio da insignificância. p.112.

${ }^{132}$ Idem ibidem.

${ }^{133}$ Idem ibidem. p.113.
} 
soma dessas condutas. É o caso daquele que furta um bombom no supermercado, no outro mês furta uma bicicleta etc ${ }^{134}$.

A discussão sobre a aplicação ou não do princípio da insignificância no caso em tela passa pela a análise se o princípio da insignificância deve utilizar apenas critérios objetivos (só analisar o fato) ou pode também permear critérios subjetivos (analisar o autor do delito).

Na doutrina, Luiz Flávio Gomes, alega que analisar a pessoa do agente nesses casos de furtos ínfimos, revela uma carga ideológica imensa, ressaltando que o direito penal é do fato e não do autor (direito penal do inimigo).

Em relação à jurisprudência, esta continua oscilante, senão vejamos:

A aplicação do princípio da insignificância está vinculada à questão de ínfima ofensividade da conduta, a ausência de periculosidade, o grau de reprovabilidade do comportamento e a inexpressividade da lesão jurídica provocada, não abarcando questões de ordem subjetiva do agente ${ }^{135}$.

Por outro lado,

HABEAS CORPUS. TENTATIVA DE FURTO. TRANCAMENTO DA AÇÃO PENAL. PRINCÍPIO DA INSIGNIFICÂNCIA. CONSTRANGIMENTO ILEGAL NÃO EVIDENCIADO. 1. Embora atualmente, em razão do alto índice de criminalidade e da consequente intranquilidade social, o Direito Penal brasileiro venha apresentando características mais intervencionistas, persiste o seu caráter fragmentário e subsidiário, dependendo a sua atuação da existência de ofensa a bem jurídico relevante, não defendido de forma eficaz por outros ramos do direito, de maneira que se mostre necessária a imposição de sanção penal. 2. Em determinadas hipóteses, aplicável o princípio da insignificância, que, como assentado pelo Ministro Celso de Mello, do Supremo Tribunal Federal, no julgamento do $\mathrm{HC} \mathrm{n}^{\circ}$ 84.412-0/SP, deve ter em conta a mínima ofensividade da conduta do agente, a nenhuma periculosidade social da ação, o reduzidíssimo grau de reprovabilidade do comportamento e a inexpressividade da lesão jurídica provocada. 3. No caso, o paciente ingressou em um estabelecimento comercial e escondeu em seu poder quatro DVDs. Percebida a conduta pela vendedora, foi solicitado que passasse pelo caixa, oportunidade em que ludibriou a funcionária e devolveu apenas dois deles. Os demais foram apreendidos posteriormente pelo segurança do shopping, avaliados em $\mathrm{R} \$ 34,90$ (trinta e quatro reais e noventa centavos). 4. Assim, não é de falar em mínima ofensividade da conduta, revelando o comportamento do agente, que a sentença diz ser "recorrente na

\footnotetext{
${ }^{134}$ GOMES, Luiz Flávio. Princípio da insignificância, p. 113.
}

${ }^{135}$ AgRg no Resp 695.473-RS, $5^{\text {a }}$ T., rel. Min. Laurita Vaz. 
prática de pequenos furtos", razoável periculosidade social e significativo grau de reprovabilidade, inaplicável, destarte, o princípio da insignificância. 5. Habeas corpus denegado $^{136}$.

\subsubsection{3}

\section{Fato único insignificante cometido por réu reincidente:}

Este ponto é outro extremamente controvertido no âmbito doutrinário e jurisprudencial, ou seja, se pode ser considerado insignificante, por exemplo, aquela subtração ínfima de um criminoso reincidente e a discussão é a mesma supracitada, se o princípio da insignificância pode ou não considerar critérios subjetivos na sua aplicação. Neste ponto, estabelecemos no tópico 4.1 que entendemos que para a aplicação do princípio em tela é imprescindível a análise do agente de forma que o direito penal, além de possuir um caráter de garantidor do cidadão em face do Estado, possui também a função de tutela dos bens jurídicos constitucionalmente garantidos, a qual ficaria comprometida, diante da sua não atuação diante dos criminosos contumazes praticando condutas formalmente típicas.

Pelo exposto acima, é importante ressaltar que não é a espécie do crime que dirá se é possível ou não a aplicação do princípio da insignificância e sim as circunstâncias do caso concreto, com as quais o aplicador da lei deverá avaliar se a conduta ou o resultado jurídico foram irrelevantes para o direito penal.

${ }^{136}$ STJ HC 120286-MG, Rel. Min. Nilson Naves, julgamento em 10/02/2009, 6 a Turma. 


\section{Conclusão}

Com base nas explanações desta dissertação, algumas conclusões se fazem necessárias.

Primeiramente, concluímos que o direito penal tem como missão principal a tutela dos bens jurídicos mais valiosos das relevantes lesões ou perigo de lesões. Da mesma forma, esclarecemos que o princípio da insignificância é princípio de decorrência lógica do princípio da intervenção mínima, que por sua vez decorre do modelo de estado adotado pela Constituição.

Em relação à natureza jurídica, bem como a localização do estudo do princípio da insignificância na teoria do crime, pudemos demonstrar que trata-se de princípio com importante função interpretativa, de forma a auxiliar o intérprete na aplicação da lei penal, de acordo com os princípio de política criminal e sua missão, excluindo da tutela penal condutas e/ou resultados incapazes de causar lesão ou perigo de lesão aos bens jurídicos mais valiosos tutelados pelo Estado. Desta forma, possui a natureza de excludente de tipicidade material, de forma a inserir na análise da tipicidade uma valoração da ação e do resultado perpetrado pelo agente.

Ao final analisamos os critérios de aplicação do princípio em tela, ressaltando que a tarefa em tela depende da análise do caso concreto, mas a criação de vetores, conforme o Supremo Tribunal Federal (a) a mínima ofensividade da conduta do agente, (b) a nenhuma periculosidade social da ação, (c) o reduzidíssimo grau de reprovabilidade do comportamento e (d) a inexpressividade da lesão jurídica provocada), pode auxiliar na aplicação mais justa da norma em tela, evitando insegurança jurídica nas decisões. Entretanto, para um aplicação mais adequada, somamos outros vetores que vislumbramos que podem auxiliar na justa aplicação do princípio da insignificância. 
Em relação a possibilidade de se analisar os antecedentes do réu para a aplicação do princípio em tela ou não, ressaltamos que a doutrina critica, alegando se tratar de direito penal do inimigo, próprio de regimes totalitários, no entanto, entendemos que, pela carga valorativa do princípio em estudo, ficou a cargo do aplicador da lei estabelecer critérios para a aplicação, de forma que não há qualquer óbice à análise do autor uma vez que o direito penal também tem a função de tutela dos bens jurídicos constitucionalmente garantidos, a qual ficaria comprometida, diante da sua não atuação diante dos criminosos contumazes praticando condutas formalmente típicas. 


\section{Referências bibliográficas}

ACKEL FILHO, Diomar. O princípio da insignificância no direito penal. Revista de Jurisprudência do Tribunal de Alçada de São Paulo. São Paulo: TJSP, v. 94, p. 72-77, abr./jun./1988.

ANTÓN ONECA, José. Derecho penal: parte general. 2. Ed. Madrid: Akal, 1986, p. 159.

BARROSO, Luís Roberto. Curso de direito constitucional contemporâneo - os conceitos fundamentais e a construção de um novo modelo. São Paulo: Saraiva, 2009, p. 86.

BATISTA, Nilo. Introdução crítica ao direito penal brasileiro. Rio de Janeiro: Revan, 1996, p. 92-94.

BIANCHINI, Alice. Pressupostos materiais mínimos da tutela penal: uma abordagem a partir dos postulados constitucionais. Tese de doutorado. São Paulo: PUC, 2001, p. 141.

CABETTE, Eduardo Luiz Santos. O mito da não existência de previsão legal do princípio da insignificância no Brasil. In: Boletim IBCCRIM ano 21, $\mathrm{n}^{\circ}$ 251, Outubro/2013 - ISSN 1676-3661. P. 16.

CANOTILHO, José Joaquim Gomes. Direito Constitucional. 7. Ed. Lisboa: Almedina, 2003, p. 225.

CARVALHO, Márcia Dometila Lima de. Fundamentação constitucional do direito penal. Porto Alegre: Sérgio Antonio Fabris Editor, 1992. P. 23-24.

CIRINO DOS SANTOS, Juarez. A moderna teoria do fato punível. Rio de Janeiro: Freitas Bastos, 2001, p. 5.

CORNEJO, Abel. Teoria de La insignificância. Buenos Aires: Ad Hoc. 1997. P. 72.

DALBORA, José Luis Guzmán. La insignificância: especificación y reducción valorativas em El âmbito de lo injusto típico. Revista brasileira de Ciências Criminais. São Paulo: RT, ano 4. n. 14, p. 41-81, abr./jun./1996.

ESTEFAM, André/GONÇALVES, Victor Eduardo Rios. Direito penal esquematizado: parte geral. 2 ed. rev. e atual. São Paulo: Saraiva, 2013, p. 133.

FERRAJOLI, Luigi. Derechos y garantias - La ley Del más débil. Madrid: Trotta, 2001, p. 20-21. 
GOMES, Luiz Flávio. Direito Penal: Fundamentos e limites do Direito Penal. Luiz Flávio Gomes, Antonio García-Pablos de Molina. - São Paulo: Editora Revista dos Tribunais, 2012. - (Coleção ciências criminais; v.1).

GOMES, Luiz Flávio. Princípio da insignificância e outras excludentes de tipicidade. $3^{\text {a }}$ ed. rev. atual. eampl.- São Paulo: Editora Revista dos Tribunais, 2013. p. 19.

GRECO, Rogério. Curso de Direito Penal parte geral.9 ed. Rio de Janeiro: Impetus, 2007. p. 4;

GUSTAVO, Junqueira/VANZOLINI, Patrícia. Manual de direito penal. São Paula: Saraiva, 2013, p. 38

LOPES, Mauricio Antonio Ribeiro. Princípio da insignificância no direito penal: análise à luz da Lei 9099/95. São Paulo: RT, 1997. p. 37-38.

MARTINELLI, João Paulo Orsini. Paternalismo jurídico-penal. Tese de Doutorado. São Paulo: USP, 2010. P. 28. Disponível em:www.teses.usp.br/teses/disponiveis/2/2136/tde.../TESE_versao_final.pdf.

MAÑAS, Carlos Vico. O princípio da insignificância como excludente de tipicidade no direito penal. São Paulo: Saraiva, 1994, p. 60.

MASSON, Cleber Rogério. Direito penal esquematizado: parte geral - vol. 1 . $5^{\text {a }}$ ed. São Paulo: Método, 2011, p. 47.

MIR PUIG, Santiago. Derecho Penal: parte geral. 3. Ed. Barcelona: P.P.U, 1990, p. 4-5. A partir de agora citado apenas como MIR PUIG, Santiago: Derecho penal: parte geral.

MULGAM, Tim. Utilitarismo: tradução de Fábio Creder. Petrópolis.RJ: Vozes, 2012, p. 162-180.

MUÑOZ CONDE. Francisco. Introducción al derecho penal. Barcelona: Bosch. 1975, p. 71-72.

PEREIRA, Carlos Frederico de O. O conceito de bem jurídico e o princípio da insignificância. Revista do Ministério Público Militar. Brasília: MPM, ano X, n. 13, 1991, p 50.

PRADO, Luiz Regis. Curso de direito penal brasileiro. Parte Geral. 2. Ed. São Paulo: RT, 2000, p. 221.

PRADO, Luiz Regis. Bem jurídico-penal e Constituição. São Paulo: Revista dos Tribunais, 1999. P. 50 e ss.

QUEIROZ, Paulo de Souza. Direito penal - Introdução crítica. São Paulo: Saraiva, 2001. p. 17-18. 
REALE JÚNIOR, Miguel.Teoria do delito. São Paulo: RT. 1998. p. 91.

ROXIN, Claus, Política criminal e sistema jurídico-penal. Trad. Int.de Luís Greco. Rio de Janeiro: Renovar, 2000, p. 33.

ROXIN, Claus. Derecho penal - parte general. Madrid: Civitas, 1997, p. 65.

SANGUINÉ, Odone. Observações sobre o princípio da insignificância. Fascículos de Ciências Penais. Porto Alegre: Sergio Antonio Fabris, ano 3, v.3, n. 1, jan./mar./1990, p. 47.

SANTOS, Lycurgo de Castro. Princípio da intervenção mínima do direito penal e crimies de menor potencial ofensivo - Lei 9099/95. Revista Justiça e Democracia. São Paulo: RT, n. 1, p. 204-205.

SARMENTO, Daniel. A ponderação de interesses na Constituição Federal. Rio de Janeiro: Lumen Juris, 2000, p. 54.

SILVA FRANCO, Alberto. Crimes hediondos. 4. Ed. São Paulo: Revista dos Tribunais, 1997, p. 67.

SILVA, Ivan Luiz da. Princípio da insignificância no direito penal. $2^{\text {a }}$ Edição. Curitiba: Juruá, 2011.

SILVA SANCHEZ, Jesús-Maria. Aproximación al Derecho penal contemporâneo. Barcelona: Ed. Bosch, 1992

TOLEDO, Francisco de Assis. Ilicitude penal e causas de sua exclusão. Rio de Janeiro: Forense. 1984. p. 8.

TOLEDO, Francisco de Assis. Princípios básicos de direito penal. 5 ed. São Paulo: Saraiva. 2000. p. 133.

VICO MAÑAS, Carlos. O princípio da insignificância como excludente da tipicidade no direito penal. São Paulo: Saraiva, 1994, p. 56.

ZACCARIOTTO, José Pedro. A Polícia Judiciária no Estado Democrático. Sorocaba: Brasilian Books, 2005.

ZUGALDIA ESPINAR, J.M. Fundamentos de derecho penal. 3. Ed. Valencia: TirantloBlanch, 1993. 